\title{
CONSCIOUS AMBIGUITY: SLAYING CERBERUS IN THE INTERPRETATION OF CONTRACTUAL INCONSISTENCIES
}

\author{
Gregory M. Duhl
}

\begin{abstract}
In United Rentals, Inc. v. RAM Holdings, Inc., Vice Chancellor Chandler rejected conscious ambiguity as a drafting principle. In the face of seemingly inconsistent provisions in the merger agreement between United Rentals and Cerberus, Vice Chancellor Chandler denied United Rentals specific performance because the equipment lessor knew that Cerberus did not think there was a specific performance remedy in the agreement and, therefore, United Rentals was not a forthright negotiator. But underlying the opinion was a message to lawyers that they have a professional and ethical obligation to draft contracts clearly. "Conscious ambiguity" undermines those obligations and is inconsistent with a consent theory of contract. This Article ends by calling for more empirical study of the ethical obligations of lawyers in drafting contracts.
\end{abstract}

* Associate Professor, William Mitchell College of Law. I thank Brianna Blazek and Erin Soldner for their research assistance; William Freivogel, Chair of the Professional Responsibility Committee of the ABA Section of Business Law, for help with the ethics issues raised in this Article; and the William Mitchell College of Law for generous summer research funding. 


\section{INTRODUCTION}

In classical Greek mythology, Cerberus, the faithful servant of Hades, was a monstrous, three-headed dog with a serpent for a tail, a lion's claws, and snakes down his back like a mane. The son of the half-woman, half-dragon Echinda and the fire-breathing giant Typhon, Cerberus guarded the gates to the underworld as the watchdog for Hades. He ensured that the spirits of the dead could enter but not leave, and that the living could not enter in search of their loved ones. In the final of his twelve labors, divine Hercules captured Cerberus from the underworld and paraded him through the Greek city of Mycenae. Hercules succeeded, ${ }^{1}$ but what happened when Cerberus rose again?

Cerberus is not simply a Greek mythological legend. Cerberus Partners, L.L.P., a private equity firm worth more than $\$ 26$ billion in late 2007, put together a group of shell entities to buy the world's largest equipment lessor, United Rentals, Inc. (URI), in a transaction worth about $\$ 7$ billion. ${ }^{2}$ The Cerberus-led entities and URI entered into an Agreement and Plan of Merger (Merger Agreement) on June 22, 2007, in which those entities agreed to buy URI for $\$ 34.50$ per share and then merge into URI. ${ }^{3}$ But in November 2007, Cerberus thwarted URI's plan to merge and maximize value for its shareholders. ${ }^{4}$ Citing uncertainty in the credit and financial markets and an unwillingness to require the deal's backers to meet their financing commitments, Cerberus called off the merger. ${ }^{5}$ Subsequently, URI, in the words of Vice Chancellor Chandler in United Rentals, Inc. v. RAM Holdings, Inc. (Cerberus), ' "journeyed to Delaware to conquer a more modern obstacle

1. There is often variation among sources in Greek mythology. For the description of Cerberus and his encounter with Hercules used in this Article, see Bernard Evslin, Cerberus (Monsters of Mythology) (1987).

2. United Rentals, Inc. v. RAM Holdings, Inc., 937 A.2d 810, 814-15 (Del. Ch. 2007).

3. $I d$.

4. Id. at 814 .

5. See Ruthie Ackerman, United Rentals vs. Cerberus: It's Up to the Judge, Forbes.com, Dec. 19, 2007, http://www.forbes.com/2007/12/19/unitedrentals-cerberus-feinberg-markets-equitycx_ra_1219markets43.html.

6. This case has come to be known among mergers and acquisitions (M\&A) practitioners and corporate law scholars as the "Cerberus" decision, and I refer to it as such throughout this Article. Cerberus Partners, L.P., an investment firm worth $\$ 26$ billion in assets, was not a party to the case. Rather, Cerberus set up the defendant entities to buy the plaintiff United Rentals, Inc., controlled the defendant entities, and was a signatory to the limited guarantee of some of the payment obligations of the defendant entities under the Merger Agreement. See United Rentals, 937 A.2d at 814. See also Ben Hallman, Anatomy of a Deal Gone South, Am. LAw., Apr. 25, 2008, http://www.law.com/jsp/article.jsp?id=1209047604522. The case also has likely taken on the name of the mythological beast Cerberus because of Vice Chancellor Chandler's 
that, rather than guards the gates to the afterlife, stands in the way of the consummation of a merger." "

After it backed out of the deal, Cerberus offered to pay URI the reverse break-up fee ${ }^{8}$ of $\$ 100$ million provided for in the Merger Agreement or to renegotiate the terms of the deal. ${ }^{9}$ URI rejected both alternatives and, five days after Cerberus's withdrawal, asked the Delaware Court of Chancery to specifically enforce the Agreement. ${ }^{10}$ Unfortunately for URI, the obstacle presented by Cerberus proved much bigger than it did for Hercules, and URI could not prevail on its interpretation of the Merger Agreement. ${ }^{11}$ As Vice Chancellor Chandler explained:

Nevertheless, like the three heads of the mythological Cerberus, the private equity firm of the same name presents three substantial challenges to plaintiff's case: (1) the language of the Merger Agreement, (2) evidence of the negotiations between the parties, and (3) a doctrine of contract interpretation known as the forthright negotiator principle. In this tale the three heads prove too much to overcome. ${ }^{12}$

While there was a provision in the Merger Agreement that gave URI the right to specific performance if the Cerberus-backed entities withdrew from the deal, that provision was subject to section $8.2(\mathrm{e})$, which provided that a $\$ 100$ million termination fee was the exclusive remedy for either party's termination of the Agreement. ${ }^{13}$ Vice Chancellor Chandler found that section 8.2(e) trumped the specific performance provision because Cerberus and the defendant entities understood that the Agreement excluded the remedy of specific performance, and because URI knew of or should have known of the

graphic portrayal of the beast in the introduction to his opinion. See United Rentals, 937 A.2d at 813.

7. See United Rentals, 937 A.2d at 813.

8. Reverse break-up fees are fees a buyer pays to a target in a merger in order to walk away from the deal. They have become much more common in M\&A agreements in recent years. See Grace Wong, The Price of Walking Away, Cnn.money.com, Aug. 28, 2007, http://money.cnn.com/2007/08/27/ markets/reverse_break_ups/index.htm. See also Jessica Jackson, Much Ado About Nothing? The Antitrust Implications of Private Equity Club Deals, 60 FLA. L. REv. 697, 712 (2008) (“[T] hese agreements also provide for a 'reverse break-up fee' to be assessed when the club fails to close under the acquisition agreement due to a breach or failure to obtain debt financing." (internal quotation marks omitted)). For example, in the sale of Neiman Marcus to two private equity firms, the sliding reverse break-up fee "prevented any ... buyer's remorse." See Bryce Klempner, Dharini Mathur, Lerato Molefe, Jen Reynolds \& Tony Uccellini, Note, Case Study: Selling Neiman Marcus, 12 Harv. Negot. L. Rev. 235, 236 (2007).

9. United Rentals, 937 A.2d at 827.

10. Id.

11. Id. at 814

12. $I d$.

13. Id. at 816 . 
defendants' understanding. ${ }^{14}$ With that holding came the introduction of the "forthright negotiator principle" into the everyday parlance of M\&A attorneys. ${ }^{15}$ Then, in the aftermath of the holding, came the revelation that big firm attorneys on both sides of the merger transaction approved the Merger Agreement while well aware of its apparent inconsistencies. ${ }^{16}$

In Cerberus, URI fell short, unlike Hercules, and walked away with the $\$ 100$ million reverse break-up fee but not the deal. ${ }^{17}$ Meanwhile, the three heads of Cerberus live on as courts and scholars continue to grapple with how to interpret business agreements. Despite the fact that problems with contract interpretation are abundant in practice, ${ }^{18}$ contract interpretation is an understudied area in the law of contracts. ${ }^{19}$ Unfortunately, law schools provide their students with little training in how to draft contracts, ${ }^{20}$ a deficit that has

14. Id. at 845 .

15. See infra note 126.

16. See infra Part III.B.

17. URI decided to accept the $\$ 100$ million reverse break-up fee and not appeal the decision of the Delaware Court of Chancery. See Press Release, Milbank, Tweed, Hadley \& McCloy, LLP, Milbank Wins Trial Victory for Client Cerberus in Delaware Chancery Court (Dec. 27, 2007), http://www.milbank.com/ en/NewsEvents/PressRelArch/Milbank_Wins_Trial_Victory_for_Client_Cerberus_in_Delaware_Chanc ery_Court.htm. See also Will Daley, United Rentals, Cerberus Agree to \$100 Million Fee (Update 2), BloOMBerG.com, Dec. 24, 2007, http:/www.bloomberg.com/apps/news?pid=20601087\&sid= alJgyJkaBQeM\&refer=home ("The termination fee is the remedy Cerberus bargained for in this deal, said Lawrence Hamermesh, a professor at Widener University Law School who specializes in Delaware corporate law. 'They basically agreed during the case they'd have to pay this fee,' Hamermesh said. 'There shouldn't be any controversy about it at this point."'). URI could have avoided the litigation and, in the minds of many, gotten the result for which it had bargained if it had accepted the $\$ 100$ million reverse break-up fee and had not filed suit. However, URI's decision to pursue litigation is what provided an interesting opinion for contracts scholars, and gave the case importance outside of M\&A circles.

18. See, e.g., Avery Wiener Katz, The Economics of Form and Substance in Contract Interpretation, 104 Colum. L. Rev. 496, 496 (2004) ("Under the modern American law of contracts, almost all applications of legal doctrine turn on questions of interpretation; and almost all questions of interpretation implicate the tension between form and substance.").

19. See, e.g., Richard A. Posner, The Law and Economics of Contract Interpretation, 83 TEx. L. REv. 1581, 1581 (2005) ("There is now a large economic literature on contracts and contract law, but the interpretation of contracts, as distinct from issues involving formation, defenses, validity, and remedies, has been rather neglected. Not entirely so; but the economic literature on contract interpretation has an abstract cast, evincing only limited interest in the relevant legal doctrines." (footnote omitted) (emphasis added)).

20. See, e.g., Stewart Macaulay, John Kidwell \& William Whitford, Contracts: Law in Action (Volume II: The Advanced Course) 243 (2d ed. 2003) (“A great many judicial opinions give meaning to contracts. This suggests there are two important lawyering tasks that students should know something about: first, [students] should know something about how to write contracts that are sufficiently clear to avoid unnecessary disputes over their meaning. Second, [students] should know something about how courts give meaning to those contracts that come before them. ... Law schools have not done well teaching about either of these problems.”). Of course, not all contracts are drafted by lawyers and not all contracts are in writing. But this Article focuses on written contracts that are primarily negotiated and 
been highlighted in recent scholarship. ${ }^{21}$ Complicating the problem is the limited mentorship available for inexperienced lawyers as they learn how to draft contracts when they get into practice. ${ }^{22}$ It has become common for attorneys to copy contracts from formbooks so that they do not have to think carefully about language, ${ }^{23}$ and to follow practices that facilitate-as in Cerberus - potentially ambiguous terms and that discount the careful drafting and reading of agreements. ${ }^{24}$

While other scholarship has focused on specific methodologies ${ }^{25}$ or doctrines of contract interpretation, ${ }^{26}$ this Article focuses on one set of facts that arises in contract cases and was at issue in Cerberus: contracts that are ambiguous because of apparent inconsistencies. What unifies these cases

drafted by lawyers.

21. See, e.g., Tina L. Stark, My Fantasy Curriculum and Other Almost Random Points 4 (Emory Univ. Sch. of Law, Law \& Econ. Research Paper Series, Paper No. 08-29, 2008), available at http://papers.ssrn.com/abstract=1158506. As one expert on contracting drafting stated, "[i]n terms of both quality and process, the drafting of business contracts is dysfunctional." Kenneth A. Adams, Dysfunctional Drafting, NAT'L L.J., Sept. 8, 2008, http://www.law.com/jsp/nlj/PubArticleNLJ.jsp?id=1202424262763.

22. See, e.g., Jeff Blumenthal, Penn Law Grad Plans to Give Contracts the Write Stuff, LeGAL INTELLIGENCER, Aug. 15, 2005, at 1 ("[G]enerations of law students have started work as corporate associates without ever having had any training in contract drafting. Instead, they have traditionally learned on the job, something that has become increasingly troublesome as the competitive pressures placed on law firms have reduced mentoring opportunities."). As Ken Adams stated about law firm associates drafting contracts, "[i]t's commonplace for a significant portion of any law firm bill for contract drafting to be attributable to having associates reinvent the wheel, with the resulting drafts being circulated - once, twice, several times - up the food chain for review then back down for remedial work." Adams, supra note 21.

23. See, e.g., James Suchan \& Clyde Scott, Unclear Contract Language and Its Effect on Corporate Culture, 29 Bus. Horizons 20, 23 (1986).

24. For one discussion of this practice, see Expert Report of Professor John C. Coates IV at 11, United Rentals, Inc. v. RAM Holdings, Inc., 937 A.2d 810 (Del. Ch. 2007) (No. 3306-CC), available at http://lawprofessors.typepad.com/mergers/files/102xx_expert_report_12062007.pdf [hereinafter Coates Expert Report] ("Another reason that such legal drafting techniques are used is they reduce the amount of blacklining and editing that must be reviewed by the numerous parties who must approve and sign off on the final documentation. If, for example, drafters can add the single sentence that contains the phrase 'subject to' or 'notwithstanding,' the various interested parties . . . can simply look at the one sentence to see the meaning of the change. If, on the other hand, a sentence is added while other sentences are modified or deleted to reflect the meaning of the new sentence and eliminate any potential apparent conflicts, more blacklining, on more pages, will have to be reviewed and evaluated by each party.").

25. See Posner, supra note 19, at 1581 ("Interpretation might seem an activity remote from economics - a subject for cognitive psychologists, epistemologists, students of linguistics, legal doctrinalists, perhaps even literary critics, rather than for economically minded lawyers — but I shall try to show that economics can be of considerable help in understanding the problems involved in interpreting contracts.").

26. See, e.g., Eric A. Posner, The Parol Evidence Rule, The Plain Meaning Rule, and the Principles of Contractual Interpretation, 146 U. PA. L. REv. 533 (1988); David Snyder, Language and Formalities in Commercial Contracts: A Defense of Custom and Conduct, 54 SMU L. Rev. 617 (2001). Of course, even scholars who write about certain doctrines often take distinct methodological perspectives. 
besides the seemingly inconsistent terms is not any doctrine of contract interpretation, but rather the courts' message to lawyers to draft contracts clearly. That message is especially striking in Cerberus, in which the attorneys knowingly left remedies provisions in the Merger Agreement that were ambiguous $^{27}$ and appeared to the court to be inconsistent. This gave rise to the much bigger issue of the interpretation of those provisions and whether URI should have been entitled to the remedy of specific performance.

Scholars have previously given attention to the benefits (especially economic) of lawyers intentionally drafting open, incomplete, and vague contracts, ${ }^{28}$ but Cerberus illustrated that lawyers also deliberately draft contracts that are inconsistent. ${ }^{29}$ Although open, incomplete, and vague terms should be encouraged in the drafting of contracts in certain circumstances, we should discourage rather than encourage ambiguity. Alan Schwartz and Robert Scott do not believe that the goal in contract interpretation is to help courts get at the "correct answer," but rather to get parties to write in "the court's language." ${ }^{30}$ But Schwartz and Scott miss the mark in not accounting for deliberate ambiguity in addressing what is the majoritarian default rule that courts should use to interpret contracts that are silent as to "judicial interpretive style." ${ }^{11}$ They suggest that the default should be the Willistonian

27. See infra Part III.B.

28. See, e.g., D. Douglas Bernheim \& Michael D. Whinston, Incomplete Contracts and Strategic Ambiguity, 88 Am. ECON. Rev. 902, 903 (1998) ("In other words, if contracts must be somewhat incomplete (due to transactions costs or limits on verifiability) then it is often optimal for parties to write contracts that are even more incomplete."); Mark P. Gergen, The Use of Open Terms in Contract, 92 Colum. L. Rev. 997, 1006 (1992) ("[O]pen terms are used because of the difficulty of writing and enforcing contracts that precisely specify performance subject to finely drawn conditions to deal with many known risks."); Gillian K. Hadfield, Judicial Competence and the Interpretation of Incomplete Contracts, 23 J. Legal Stud. 159, 159 (1984) ("In recent years writers in both economics and law have recognized the prevalence and importance of incomplete contracting in the design of markets and organizations."); Posner, supra note 19, at 1582-83; Robert E. Scott, A Theory of Self-Enforcing Indefinite Agreements, 103 Colum. L. Rev. 1641, 1645 (2003) ("Fairness theory better explains the behavior of contracting parties as well as the durability of the indefiniteness doctrine which, by narrowing the domain of legal liability, preserves space for parties to exploit opportunities to reciprocate."); Jean Tirole, Incomplete Contracts: Where Do We Stand?, 67 ECONOMETRICA 741, 742-43 (1999).

29. Of course, sloppiness is another cause of ambiguous drafting. See infra Part III.A.1. Furthermore, a party with less bargaining power than a counterparty to an agreement, e.g., a consumer entering into a form contract, might lack any "choice" but to accept ambiguous language in an agreement. See, e.g., Mo Zhang, Contractual Choice of Law in Contracts of Adhesion and Party Autonomy, 41 AKRON L. REv. 123, 139-40 (2008). My discussion in this Article focuses on lawyers whose clients have as much or more bargaining power than the other party or parties to an agreement.

30. See Alan Schwartz \& Robert E. Scott, Contract Theory and the Limits of Contract Law, 113 YALE L.J. 541, 569, 572 (2003).

31. See id. at 569 . 
four-corners rule, ${ }^{32}$ which bars parties from introducing extrinsic evidence to show that the contract is ambiguous. The Willistonian approach enables parties to include ambiguous language in contracts when it suits their interests (i.e., "to get the deal done"), at the expense of courts having to make an imprecise judgment about whether the contract is ambiguous, which risks getting the result wrong (as Vice Chancellor Chandler might have done in Cerberus without a trial). ${ }^{33}$

Fortunately, the courts, by and large, have correctly decided cases with inconsistent contract provisions. ${ }^{34}$ Nonetheless, courts should discourage lawyers from drafting intentionally ambiguous contracts in the rush to get a deal done. Part of lawyers' professional obligation is to draft clear contractual language for their clients. ${ }^{35}$ Furthermore, lawyers have an ethical obligation to reveal known inconsistencies that exist in the agreements that they are drafting, and not to contribute to such inconsistencies. ${ }^{36}$ Where the language of the agreement is ambiguous, there is a risk - especially from application of the four-corners rule - of courts not enforcing the obligations to which the parties consented. ${ }^{37}$ This risk poses a challenge to consent and other autonomy-based theories of contract. ${ }^{38}$

32. Id. Judge Posner asks whether this is a rule of interpretation because "[i]f the contract is clear, there is no need to interpret it. If it is unclear, the rule provides no guidance to extracting its meaning." Posner, supra note 19, at 1597. But the question of whether a contract is clear can be unclear itself (as it was, perhaps, in Cerberus), which leads to the question of whether the court will look at extrinsic evidence in answering this threshold question. The four corners rule is more limiting than the parol evidence rule, which bars the admissibility of extrinsic evidence of precontractual negotiations that contradicts the terms of an integrated agreement. See id. at 1602-03. The four corners rule also prohibits evidence of terms that supplement the terms of a written agreement. $I d$. at 1603 . If terms or provisions of a contract are inconsistent, parol evidence should always be allowed to interpret that ambiguity, so the parol evidence rule is beyond the scope of this Article. However, because the four corners rule carries the risk of a court not identifying ambiguity in the first place, this Article addresses that rule in Parts II.D and V.C.

33. See infra note 113.

34. But see infra Part II.D.

35. See infra Part IV.B.1. Whether language is clear or unclear is relative and contextual. In this Article, "unclear language" is language from which it is unclear to what the parties assented at the time of contracting.

36. See infra Part IV.B.2.

37. Contractual ambiguity interferes with the courts' ability to ascertain parties' intentions from objective (as opposed to subjective) evidence. See, e.g., Joseph M. Perillo, The Origins of the Objective Theory of Contract Formation and Interpretation, 69 FordHAM L. REV. 427, 427 (2000) ("The objective theory of contract formation and interpretation holds that the intentions of the parties to a contract or alleged contract are to be ascertained from their words and conduct rather than their unexpressed intentions.").

38. See Randy Barnett, A Consent Theory of Contract, 86 CoLum. L. Rev. 269, 300-09 (1986), for a discussion of the consent theory of contract: "[A] consent theory specifies that a promisor incurs a contractual obligation the legal enforcement of which is morally justifiable by manifesting assent to legal 
Part I of this Article discusses five types of interpretation and implication $^{39}$ problems: (i) open terms, (ii) incompleteness, (iii) vagueness, (iv) ambiguity, and (v) inconsistent terms. Part II primarily analyzes three doctrines courts use in interpreting inconsistent contract provisions: the forthright negotiator principle, contra proferentem, ${ }^{40}$ and the four corners rule. Part II suggests that despite Vice Chancellor Chandler's application of the forthright negotiator principle in Cerberus, the core of the opinion delivers a message to deal lawyers to draft contract language clearly. Part III uses Cerberus to illustrate that just as lawyers intentionally draft contracts with open, incomplete, or vague terms, they sometimes deliberately draft contracts with inconsistent provisions. While there are perhaps reasons to do so (i.e., to get a deal done that would have fallen through otherwise), ${ }^{41}$ Part IV argues

enforcement and thereby invoking the institution of contract." Id. at 305. While Part IV.A of the Article explains why autonomy-based theories of contract are more helpful than efficiency-based theories in addressing the challenges posed by intentional ambiguity, this Article does not give much attention to defending a consent theory as the preferred autonomy-based theory of contract. Additionally, consent and other autonomy-based theories have limitations in their application to certain types of contracts where one party has little or no bargaining power (e.g., form contracts). See, e.g., Jean Braucher, Contract Versus Contractarianism: The Regulatory Role of Contract Law, 47 Wash. \& LeE L. Rev. 697, 712 (1990) (recognizing that consent plays a central role in contract law but arguing that contract law must set "appropriate limits of consent as a rationale for contract enforcement, particularly for enforcement of very harsh terms"). However, even in form contracts, a consent theory certainly favors clear language (or "plain English" as some call it). See infra Part IV.A.

39. Interpretation is the process by which courts give meaning to the words in a contract; whereas implication is the process by which courts supply terms to the contract that are not provided by the parties. E. Allan Farnsworth, Contracts $\S \S 7.7,7.16$, at 439, 483 (4th ed. 2004). Of course, a court only supplies a term after interpreting the contract and finding that the contract does not provide for the contingency that arose. Id. $§ 7.16$, at 483 . The first two problems (open terms, incompleteness) discussed in Part I are issues of implication, and the final three (vagueness, ambiguity, inconsistent terms) are issues of interpretation.

40. Contra proferentem is a rule of interpretation that states that ambiguous language in a contract should be interpreted against the party who drafted the contract. It usually only applies where the drafting party has superior bargaining power to the non-drafting party. 11 RiCHARD A. LORD, A TREATISE ON THE LAW OF CONTRACTS $\S 32: 12$, at 471-80 (4th ed. 1999) ("Indeed, any contract of adhesion, a contract entered without any meaningful negotiation by a party with inferior bargaining power, is particularly susceptible to the rule that ambiguities will be construed against the drafter.").

41. See, e.g., Coates Expert Report, supra note 24, at 2 ("Attorneys negotiating buyout and other M\&A agreements commonly economize on time and costs by using terms such as 'subject to' and 'notwithstanding' rather than attempting to synthesize provisions that would otherwise be partly or wholly potentially in conflict with one another."); Posting of Jeffrey Lipshaw to Concurring Opinions, http://www.concurringopinions.com/archives/2007/12/more_davidoffri_1.html(Dec. 24, 2007, 09:42 EST) ("My casual empiricism says lawyers [calculate the risk of losing in court versus the risk of not getting the deal done] all the time, in one form or another, but that the conclusion is almost always to let either difficult construction or even ambiguity stand for fear of wrecking the deal. . . . If I were to resort to behavioral psychology and economics, I'd suggest that risk aversion accounts for the ex ante choice- - between taking the present deal and the risk of either losing the deal or having an adverse outcome in litigation, we select 
that lawyers have professional and ethical obligations to refrain from intentionally drafting contracts with ambiguity, and that those obligations are consistent with a consent theory of contract law. Part V rejects the four corners rule, but accepts the forthright negotiator principle and contra proferentem as doctrines of interpretation that discourage attorneys from intentionally drafting ambiguous language. Part VI concludes the Article and poses some empirical questions for further study.

\section{Types of Interpretation and Implication Problems}

There are five types of interpretation and implication problems that frequently arise in agreements: (i) open terms, (ii) incompleteness, (iii) vagueness, (iv) ambiguity, and (v) inconsistency. ${ }^{42}$ Commentators $^{43}$ and courts $^{44}$ frequently confuse these terms; defining the types of interpretation problems that arise makes it easier to discuss them. ${ }^{45}$

\section{A. Open Terms}

If parties reach an agreement but intentionally leave a term to be "fixed by later agreement between them," that term is "open." ${ }^{46}$ Contracting parties can decide to postpone the negotiation over certain terms because they want to wait for the occurrence of future events or to minimize the time and costs spent negotiating. ${ }^{47}$ For example, Farmer Frank agrees to sell 100 acres of farmland to Grower George in one year, and they postpone setting the price

the certainty of doing the deal—and hindsight bias accounts for the ex post analysis."). Professor Lipshaw raises an interesting empirical question - to what extent do lawyers draft provisions they know are unclear. I agree with Professor Lipshaw that the practice is widespread, and I raise the need for such empirical analysis in Part VI of this Article.

42. Contracts with inconsistent terms are ambiguous; I analyze them in a separate category, however, because ambiguity is a matter of degree, and contracts with inconsistencies perhaps best illustrate that lawyers deliberately draft contracts that they know are ambiguous.

43. See also Posner, supra note 19, at 1583 (using "deliberate ambiguity" to discuss open terms).

44. See, e.g., Frigaliment Importing Co. v. B.N.S. Int'1 Sales Corp., 190 F. Supp. 116, 118 (S.D.N.Y. 1960 ) ("[T]he word "chicken' standing alone is ambiguous."). In this classic case, the word "chicken" in the contract was vague, not ambiguous, because it had many possible meanings in the context of the parties' contract. See infra note 70 and accompanying text. The court concluded that "chicken" was used by the parties in the "broader sense" and included stewing chickens. Frigaliment Importing, 190 F. Supp. at 121.

45. Many of these interpretation problems also arise in the context of whether the agreement is a contract in the first place. In this Article, however, I am more interested in how courts supply or interpret terms when they find the existence of a contract.

46. See FARNSWORTH, supra note $39, \S 3.7$, at $119-21$.

47. Id. $\S 3.7$, at $119-20 \& \mathrm{n} .15$. 
until they know the market price for the farmland at that time; they "agree to agree" on the price of farmland in one year. However, what if Frank and George cannot reach an agreement on the price of the farmland one year later?

The traditional approach to this type of problem is that there is no enforceable contract. ${ }^{48}$ The supposition of this approach is that the parties intended that there would be no contract if they could not reach agreement on the open term. ${ }^{49}$ For example, in Walker $v$. Keith, the court found the parties' failure to set the rent for a renewal of a ten-year lease fatal to the enforceability of the renewal. ${ }^{50}$ Once the parties could not agree to a price for the renewal, "their rights were no longer fixed by the contract." ${ }^{11}$ The court was not only concerned with what the parties had intended at the time of the contract, but also with the burden on the court of enforcing open terms: "We realize that litigation is oftentimes inevitable and courts should not shrink from the solution of difficult problems. On the other hand, courts should not expend their powers to establish contract rights which the parties, with an opportunity to do so, have failed to define." ${ }^{2}$

Despite the concerns about the judicial efficiency of courts filling open terms, courts in recent decades have found contracts despite open terms and have used default rules to supply those terms. ${ }^{53}$ For example, if there is no price term for the sale of goods under the Uniform Commercial Code (U.C.C.) because the parties "agreed to agree" to the price, courts can supply the term unless the parties did not intend to be bound absent agreement as to the price. ${ }^{54}$ U.C.C. section $2-305$ reads:

48. See id. § 3.7, at 120. Cf. Nellie Eunsoo Choi, Note, Contracts with Open or Missing Terms Under the Uniform Commercial Code and the Common Law: A Proposal for Unification, 103 CoLum. L. REv. 50, 56-58 (2003) (distinguishing the traditional common law approach to open or missing terms with the modern U.C.C. approach to those terms).

49. See FARNSWORTH, supra note $39, \S 3.7$, at 120 . Whether this premise is true empirically is a difficult question - probably sometimes it is, sometimes it is not, and sometimes the parties have not considered the question.

50. 382 S.W.2d 198, 204 (Ky. 1964).

51. $I d$.

52. $I d$.

53. See FARNSWORTh, supra note $39, \S 3.7$, at 120 . Courts fill open terms just like they do for missing terms in incomplete contracts. See infra Part I.B. Courts commonly find a contract, despite open or missing terms, and the critical question is what term or terms the courts should supply.

54. See, e.g., Koch Hydrocarbon Co. v. MDU Res. Group, Inc., 988 F.2d 1529, 1535 (8th Cir. 1993) (stating the district court could set a reasonable price for the natural gas if it could not discern from the evidence the price that the parties had intended if there was deregulation followed by a market drop); Lickley v. Max Herbold, Inc., 984 P.2d 697, 700-01 (Idaho 1999) (holding the court could decide on price where parties intended to enter into a contract but failed to negotiate price). 
(1) The Parties if they so intend may conclude a contract for sale even if the price is not settled. In such a case the price is a reasonable price at the time for delivery if:

(a) nothing is said as to price;

(b) the price is left to be agreed by the parties and they fail to agree; or

(c) the price is to be fixed in terms of some agreed market or other standard as set or recorded by a third person or agency and it is not so set or recorded..$^{55}$

For example, if Oscar Orchard agrees to sell 100 bushels of apples to Barbara Baker on June 15, 2009, with the price to be set upon delivery on December 31, 2009, and the parties cannot agree on a price, it is probably consistent with the parties' expectations for the court to set the contact price at the market price of apples on December 31, 2009. Of course, if Oscar and Barbara had agreed not to be bound if they failed to agree on a price, there would be no contract. ${ }^{56}$

Parties may not provide for all contingencies in a contract because all circumstances are unknown at the time of contracting (e.g., the market price at a later date) or, as Judge Posner notes, they may do so because they cannot agree on all terms at the time of entering into the contract. He writes, "Deliberate ambiguity may be a necessary condition of making the contract; the parties may be unable to agree on certain points yet be content to take their chances on being able to resolve them, with or without judicial intervention, should the need arise. ${ }^{, 57}$ Whether courts should enforce contracts with open terms is beyond the scope of this Article; however, the practice of writing agreements with such terms is at least defendable as efficient because it minimizes transaction and enforcement costs and promotes exchanges. ${ }^{58}$ This is the case even if courts are more conservative in enforcing agreements with open terms because parties can rely on self-enforcement rather than legal enforcement of their relationships. ${ }^{59}$

55. U.C.C. $\S 2-305(2002)$.

56. See id. §2-305(4).

57. Posner, supra note 19, at 1583 . Judge Posner's use of the word "ambiguity" is technically wrong here. The problem he describes is more a specific type of vagueness because there are many possible ways for a court to fill open terms. See supra note 44; infra note 68. Judge Posner notes that the other cause of incompleteness is that performance of contracts occurs over time, so the costs of foreseeing and accounting for all future contingencies that may affect parties over the course of a contract are prohibitive. See Posner, supra note 19, at 1582 .

58. See, e.g., Gergen, supra note 28 , at 1006-07.

59. See Scott, supra note 28, at 1643-45. 


\section{B. Incompleteness}

Contracts are, by definition, incomplete. ${ }^{60}$ Consequently, completeness is a matter of degree ${ }^{61}$ Parties are not required to include terms in agreements that provide for all contingencies in order to have an enforceable contract. ${ }^{62}$ An agreement with open terms - where the parties "agreed to disagree" about a term or not to provide for a term - is different than an incomplete contract, in which the parties never anticipated a situation that arose under the contract, or anticipated the situation but decided not to provide for it in the contract. ${ }^{63}$ If a court is convinced that there is a contract despite the incompleteness, it will use "gap fillers" or "statutory terms" to supply the missing terms ${ }^{64}$ For example, if parties do not specify the warranties in a contract for the sale of goods, the seller-if a merchant of goods of that kind - gives an implied warranty of merchantability to the buyer, unless such a warranty is otherwise properly disclaimed or modified. ${ }^{65}$

60. See, e.g., id. at 1641 ("All contracts are incomplete. There are infinite states of the world and the capacities of contracting parties to condition their future performance on each possible state are finite."). Professor Scott discusses whether agreements are "indefinite" (or "uncertain") and whether agreements are "incomplete" interchangeably. See id. at 1647-61. An "incomplete contract" is a contract nonetheless, and potentially raises questions of interpretation, which are the focus of this Article. To the extent that Professor Scott uses "incomplete" as a synonym for "indefiniteness" or "uncertainty," he is correct that an agreement must be definite enough to be enforceable. See FARnSWORTH, supra note 39, § 3.1, at 108.

61. Karen Eggleston, Eric A. Posner \& Richard Zeckhauser, The Design and Interpretation of Contracts: Why Complexity Matters, 95 Nw. U. L. Rev. 91, 91 (2000) (“Courts and contracts scholars now understand that a contract might be more or less 'complete,' in the sense of describing the obligations of parties in different future states of the world.").

62. See, e.g., Echols v. Pelullo, 377 F.3d 272, 276 (3d Cir. 2004) (holding promoter and boxer had a contract despite that they had to negotiate boxer's compensation for each bout in which he appeared because the agreement established a relationship between the parties, "a relationship in which Echols promised to fight exclusively for Banner, and Echols desired Banner's services on an ongoing basis"); Interstate Litho Corp. v. Brown, 255 F.3d 19, 27 (1st Cir. 2001) (stating parties provided all of the "essential terms" of the agreement that were sufficient for there to be a contract, even though the agreement did not state the date by which the two printing presses were going to be refurbished); Colfax Envelope Corp. v. Local No. 458-3M, Chi. Graphic Commc'ns Int'1 Union, 20 F.3d 750, 752 (7th Cir. 1994) ("Most contract disputes arise because the parties did not foresee and provide for some contingency that has now materialized — so there was no meeting of minds on the matter at issue - yet such disputes are treated as disputes over contractual meaning, not as grounds for rescinding the contract and thus putting the parties back where they were before they signed it.").

63. See FARnSwOrTh, supra note $39, \S 7.15$, at $480 \&$ n. 2 .

64. For example, with the sale of goods, Article 2 of the U.C.C. fills gaps for parties with a fairly comprehensive set of default rules. See Daniel Keating, Sales: A Systems Approach 6 (3d ed. 2006). Of course, the default provisions of the U.C.C. can be superseded through express terms, or by course of performance, course of dealing, or usage of trade. See id. at 10.

65. U.C.C. § 2-314 (2002). See also KeAting, supra note 64, at 9. 
Regardless of whether courts enforce or parties self-enforce incomplete contracts, lawyers cannot avoid drafting them. ${ }^{66}$ Incomplete contracts can achieve the same efficiencies as contracts with open terms. ${ }^{67}$

\section{Vagueness}

A vague term in a contract is one that has a range of meanings in context. ${ }^{68}$ As Professor Farnsworth wrote, "a word is vague to the extent that it defines not a neatly bounded class but a distribution around a central norm. ${ }^{" 69}$ In discussing the vagueness case perhaps best known to first-year law students, contracts professors have asked for decades, "What is a chicken?"70 Or, suppose $A$ Corp. agrees to buy $B$ Corp. subject to $A$ Corp.'s ability to obtain financing. $A$ Corp. promises to use "best efforts" to obtain financing and close the deal. "Best efforts" does not have a discrete number of meanings in context and raises several interpretive questions once we assume that the agreement is definite enough to enforce. ${ }^{71}$ How many lenders does $A$ Corp. have to contact? What terms does $A$ Corp. have to accept? ${ }^{72}$

66. See Scott, supra note 28, at 1641 .

67. See supra note 60 and accompanying text; see also supra note 28 .

68. A contract with a vague term is, perhaps, a type of "incomplete contract" where the parties give a term that is not specific enough to cover a contingency that arises. All incomplete contracts do not have vague terms, however, because vagueness presupposes that there is a term to interpret in the first place. See, e.g., infra note 72 and accompanying text. For a definition of an incomplete contract that encompasses contracts with vague terms, see Charles J. Goetz \& Robert E. Scott, Principles of Relational Contracts, 67 VA. L. REV. 1089, 1091 (1981) ("A contract is relational to the extent that the parties are incapable of reducing important terms of the arrangement to well-defined obligations. Such definitive obligations may be impractical because of inability to identify uncertain future conditions or because of inability to characterize complex adaptations adequately even when the contingencies themselves can be identified in advance.").

69. FARNSWORTH, supra note $39, \S 7.8$, at 441.

70. See Frigaliment Importing Co. v. B.N.S. Int'1 Sales Corp., 190 F. Supp. 116 (S.D.N.Y. 1960); see also supra note 44.

71. See supra note 60.

72. Of course, even if $A$ Corp. had not promised to use "reasonable efforts" to obtain financing, a court could have imposed a term for $A$ Corp. to use "reasonable efforts" to do so. See, e.g., Wood v. Lucy, Lady Duff-Gordon, 118 N.E. 214, 215 (N.Y. 1917) (holding that the plaintiff, who had an exclusive right to market the defendant's designs, had to use "reasonable efforts to bring profits and revenues into existence"). However, there is sometimes a difference between cases in which courts "disambiguate" a contract, or interpret a term provided by the parties, and cases in which courts fill gaps, or fill in terms in the contract. See Posner, supra note 19, at 1584-85. The latter more often also involve the threshold determination of whether a contract exists (and, therefore, whether the court should fill the gap in the first place). 
The term "best efforts" is vague and, thus, the contract between $A$ Corp. and $B$ Corp. is incomplete. ${ }^{73}$ Most likely, $A$ Corp. and $B$ Corp. can self-enforce $A$ Corp.'s obligation to use "best efforts" without court intervention. ${ }^{74}$ Regardless of whether a contract, such as that between $A$ Corp. and $B$ Corp., requires legal enforcement at some point, the lawyers' decision not to define vague terms more precisely saves on transaction costs in negotiating the deal and gives parties flexibility in completing a deal that perhaps has economic efficiencies. ${ }^{75}$ However, to the extent that the lawyers used "best efforts" to mask that their clients had different understandings of the scope of $A$ Corp.'s obligation to seek financing, their drafting raises some of the same issues that an ambiguous term raises, which is the focus of the remainder of this Article.

\section{Ambiguity}

An ambiguous term in a contract, as opposed to a vague term, is one in which there are two different meanings in context, such that one meaning excludes the others. ${ }^{76}$ The principal type of ambiguity is semantic or lexical

73. See supra note 68 .

74. See Schwartz \& Scott, supra note 30, at 557-59.

75. See supra note 28.

76. Professors Eskridge and Frickey explain, "Ambiguity creates an either/or situation, while vagueness creates a variety of possible meanings.” William M. EsKridge, JR. \& Philip F. Frickey, CASeS and Materials on Legislation: Statutes and the Creation of Public Policy 839 (1988). For further explanations of the difference between vagueness and ambiguity, see Jill C. Anderson, Just Semantics: The Lost Readings of the Americans with Disabilities Act, 117 YALE L.J. 992, 997 \& n.25 (2008) ("The argument presented in this Article is not based on vagueness, i.e., the notion that the regarded-as language is blurry at its conceptual edges and has been read too narrowly at those edges. Rather, my claim concerns the availability of clear alternate readings of that language to the one reading tacitly endorsed by the courts."); John F. Decker, Addressing Vagueness, Ambiguity, and Other Uncertainty in American Criminal Laws, 80 Denv. U. L. Rev. 241, 260-61 (2002) ("Scholars have, of course, managed to see a difference by pointing out that while a vague statute does not satisfactorily define the proscribed conduct, one that does define prohibited conduct with some precision, but is subject to two or more different interpretations, is ambiguous."); E. Allan Farnsworth, "Meaning” in the Law of Contracts, 76 YALE L.J. 939, 953 (1967) ("Ambiguity, properly defined, is an entirely distinct concept from that of vagueness. A word that may or may not be applicable to marginal objects is vague. But a word may also have two entirely different connotations so that it may be applied to an object and be at the same time both clearly appropriate and inappropriate, as the word 'light' may be when applied to dark feathers. Such a word is ambiguous."); Dru Stevenson, Toward a New Theory of Notice and Deterrence, 26 CARdozo L. REv. 1535, 1585 n.205 (2005) ("There is, of course, a difference between 'vagueness' and 'ambiguity' in statutes; the former means the terms could describe an almost infinite range of activities (no clear lines at all), while the latter describes (typically a single term or phrase) that could have two meanings, and a court must decide which to use. The two are treated differently by the judiciary: vagueness can become a constitutional issue (depriving citizens of due process), which makes a statute void, while ambiguity is simply resolved with a tilt in favor of the defendant (the 'rule of lenity')."). 
ambiguity. ${ }^{77}$ For example, if Mary says to John, "I saw a light truck," it is unclear whether "light" refers to the color of the truck or its weight. However, ambiguity is context-dependent. For example, Mary writes to John that she will tutor John at 9:00 each Friday, and John was aware that Mary only tutors from 9:00 A.M. to 5:00 P.M., it is unambiguous that the parties intended for the tutoring to take place at 9:00 in the morning. The focus of this Article is on language that is ambiguous in context.

Under an objective theory of contacts, "the court must first determine whether the contractual language in dispute is ambiguous. When the contract language, read in the context of the entire contract, is not reasonably susceptible to more than one meaning, this 'objective' meaning will govern." ${ }^{17}$ However, if the parties shared the same meaning of an ambiguous term at the time of contract, the prevailing view is that a court should interpret the contract in accordance with that meaning, even if under an objective standard of reasonableness the term would mean otherwise. ${ }^{79}$ When parties had different understandings of a material term that is ambiguous, and both parties had no reason to be aware of the other party's understanding, the ambiguity is latent, and a court usually either finds that no contract was formed ${ }^{80}$ or

77. Mary Ann Corbett, Language Problems in Rules: Avoiding Ambiguity and Vagueness 13 (2007), www.health.state.mn.us/rules/manual/ambiguitypart1.ppt. By contrast, syntactic ambiguity "[h]appens when there's doubt about how one word affects another." Id. at 25. For example, does "private and accredited law schools" mean "private law schools and accredited law schools" or "law schools that are both private and accredited"? For another example, see Hamann v. Crouch, 508 P.2d 968, 970 (Kan. 1973) (noting the ambiguity in a contract reading, "[p]rofessional employees granted leaves will, if possible, be reinstated in positions that are similar to the position held when granted the leave" by explaining, "[i]n short, [appellant] claims the sentence means that he had an absolute right to reinstatement and that 'if possible' it would be in a position similar to that previously held. Appellees, on the other hand, interpret the sentence to mean that acceptance of a leave of absence by an employee terminated his contract and that if he desired to return he would be reinstated 'if possible' - meaning reinstatement only if a position were available."). Problems also arise with regard to the use of "and" and "or." See CoRBETt, supra, at 42; see also FARNSWORTH, supra note $39, \S 7.8$, at 443.

78. Bell Atl. Meridian Sys. v. Octel Commc'ns Corp., Civ. A. No. 14348, 1995 WL 707916, at *6 (Del. Ch. Nov. 28, 1995).

79. See Farnsworth, supra note 39, § 7.9, at 446. But see Eustis Mining Co. v. Beer, Sondheimer \& Co., 239 F. 976, 984 (S.D.N.Y. 1917) ("It makes not the least difference whether a promisor actually intends that meaning which the law will impose upon his words.").

80. See, e.g., Konic Int'l Corp. v. Spokane Computer Servs., Inc., 708 P.2d 932, 934 (7th Cir. 1985) (holding that there was no contract where parties disagreed on whether "fifty-six twenty" meant $\$ 5,620$ or \$56.20); Oswald v. Allen, 417 F.2d 43, 44 (2d Cir. 1969) (holding that "minds of the parties had not met" because the plaintiff thought she was buying all the Swiss coins of the defendant, but the defendant only thought she was selling Swiss coins segregated by her into a special collection and "denominated by her as the Swiss Coin Collection" (internal quotation marks omitted)). 
rescinds the contract on the basis of mutual misunderstanding. ${ }^{81}$ Where one party knew or had reason to know that the other party attached a different meaning to an ambiguous term, courts often enforce the contract and interpret the ambiguous term consistent with the other party's meaning. ${ }^{82}$ How courts do so is the subject of Part II of this Article.

\section{E. Inconsistency}

Inconsistent terms (or provisions) ${ }^{83}$ are ambiguous because one term or provision excludes the other and vice versa.$^{84}$ For example, what if a vesting schedule for insurance commissions upon an employee's retirement is different in the former employee's contract than in the agent's manual incorporated in the contract? ${ }^{85} \mathrm{Or}$, a contract provides for the buyer to pay the seller $\$ 1.25$ per thousand feet of timber cut and removed from the seller's land, but also provides for the buyer to pay the seller $\$ 1,400$ to remove all timber from the tract of the seller's land ${ }^{86}$ Or, a provision of a contract requires exercise of a warrant prior to April 5, 1981, and another provision of

81. See, e.g., Colfax Envelope Corp. v. Local No. 458-3M, Chi. Graphics Commc'ns Int'l Union, 20 F.3d 750, 754 (7th Cir. 1994).

82. See, e.g., id. (stating that, where promisor was aware that the contract was unclear and interpretation would be necessary, it should not be able to escape liability by the court finding there was no contract); Centron DPL Co. v. Tilden Fin. Corp., 965 F.2d 673, 675 (8th Cir. 1992) ("It is well settled, however, that where only one party knows or has reason to know of the different meaning attached by the other, that party is bound by the other party's meaning."). See also FARNSwORTH, supra note 39, § 7.9, at $448-50$.

83. There is a difference between contracts with inconsistent terms or provisions and contracts where a specific provision provides a limitation to a general provision. For an example of the latter, see Perry \& Wallis, Inc. v. United States, 427 F.2d 722, 724 (Ct. Cl. 1970) ("This contract specifically defines 'actual necessary cost' as including 'all reasonable expenditures for material, labor, and supplies,' and then goes on to say that in no case will actual and necessary costs include an allowance for any 'general expense not directly attributable to the extra work.' We read this provision as plainly and directly refuting plaintiff's proffered interpretation. The term 'actual necessary cost' is narrowed down to exclude any and all expenses not directly attributable to the extra work. This is a clear expression of the government's intention to limit the base cost formula so as to exclude what plaintiff is now seeking." (emphasis added)).

84. Another situation arises when a provision in the contract cannot be performed because of a statute precluding its performance. In such cases courts have held that interpreting the provision in a way that is inconsistent with the statute is not reasonable. See, e.g., Sunshine v. M.R. Mansfield Realty, Inc., 575 P.2d 847, 849 (Colo. 1978) (holding that lessors' interpretation of guaranty as 100 percent Small Business Association guaranty was unreasonable because 100 percent guaranty was not allowed by federal law).

85. See Klapp v. United Ins. Group Agency, Inc., 663 N.W.2d 447, 451-52 (Mich. 2003); see also infra notes 139-49 and accompanying text.

86. See Hardin v. Dimension Lumber Co., 13 P.2d 602, 602 (Or. 1932); see also infra notes 164-71 and accompanying text. 
the contract requires exercise before or on April 5, 1981 $?^{87}$ Can the warrant be exercised on April 5, 1981? Provisions that were apparently inconsistent were the source of ambiguity in Cerberus, and this Article focuses on this specific type of ambiguity in Part II.

\section{Doctrines to InTERPRET INCONSISTEnt TERmS}

This Part discusses three doctrines that courts use to interpret inconsistent terms or provisions: (i) the forthright negotiator principle, (ii) contra proferentem, and (iii) the four corners rule. What is often at stake in the cases in which courts apply these doctrines is the message to parties to draft agreements clearly.

\section{A. Cerberus and the Forthright Negotiator Principle}

According to Vice Chancellor Chandler, "[t]he forthright negotiator principle provides that, in cases where the extrinsic evidence does not lead to a single, commonly held understanding of a contract's meaning, a court may consider the subjective understanding of one party that has been objectively manifested and is known or should be known by the other party." ${ }^{\text {" Contracts }}$

87. In Swiss Bank Corp. v. Dresser Industries, Inc., 141 F.3d 689, 690 (7th Cir. 1998), Swiss Bank had a warrant to purchase one million shares of Dresser stock. Id. at 690. The contract stated that Swiss Bank had to exercise the option "prior to five years from [April 5, 1991]," or by April 5, 1996. Id. The legend also stated: "Void five years from date of issuance." Id. When the original purchaser of the warrant assigned it to O'Connor Investments (which sold it to Swiss Bank), Dresser reissued O'Connor a replacement certificate that stated on the first page that the warrant had to be exercised prior to April 5, 1996 (or by April 4, 1996). Id. at 690-91. The second page of the replacement certificate still stated that O'Connor had until the closing date or prior to April 6, 1996, to exercise the warrant. $I d$. at 691. As the first page of the replacement certificate contradicted both the second page and the original certificate, there could have been a question whether Swiss Bank could exercise the warrant on April 5, 1996. However, Swiss Bank waited until April 8, 1996, to exercise the certificate and argued that it was entitled to do so because April 5, 1996, was Good Friday and April 6 and 7 were the weekend. See id. at 691-92. The court found that it did not have to resolve the ambiguity as to whether Swiss Bank could exercise the warrant on April 5 because Swiss Bank could not delay exercising the warrant solely because of a legal holiday and the weekend. Id. at 694 .

88. United Rentals, Inc. v. RAM Holdings, Inc., 937 A.2d 810, 836 (Del. Ch. 2007). The only authority cited by the court in that case to support the principle was Restatement (Second) of Contracts $\S 201(2)$ (1981). See infra note 129. For an application of the forthright negotiator principle after Cerberus, see the following: Abuy Dev. L.L.C. v. Yuba Motorsports, Inc., No. 4:06CV799SNL, 2008 WL 1777412, at *7, 11 (E.D. Mo. Apr. 16, 2008) (holding that, although "Defaulting Member" in operating agreement was ambiguous, parol evidence showed that both parties had same subjective understanding of the term); In re IAC/InterActive Corp., 948 A.2d 471, $501 \mathrm{n} .123$ (Del. Ch. 2008) ("As an aside, this testimony at the very least supports application of the forthright negotiator principle.”). 
scholars have discussed this doctrine for decades. ${ }^{89}$ Vice Chancellor Chandler's opinion in Cerberus brought the forthright negotiator principle to the attention of deal lawyers and litigators, so this Part now turns to the facts of that case.

Plaintiff United Rentals, Inc. (URI), is the largest equipment rental company in the world (based on revenue).$^{90}$ In spring 2007, it set out to explore strategic alternatives to maximize the value of the company for shareholders, which included soliciting offers for the sale of the company. ${ }^{91}$ URI offered itself up for sale in an auction by sending a draft merger agreement to potential buyers, including Cerberus Capital Management, L.P. (Cerberus). ${ }^{92}$ On June 22, 2007, URI concluded the auction process and entered into an "Agreement and Plan of Merger" (Merger Agreement) with defendants RAM Holdings, Inc. (RAM Holdings), and RAM Acquisition Corp. (RAM Acquisition and, collectively, RAM), which were shell companies with de minimis assets set up by Cerberus to effectuate the Merger Agreement. ${ }^{93}$ Under the Merger Agreement, RAM agreed to buy all of the shares of URI for $\$ 34.50$ per share, for a total transaction value of $\$ 7$ billion, which included the repayment or refinance of URI's existing debt. ${ }^{94}$ RAM Acquisition Corp. was to be merged into URI, the surviving corporation under the Merger Agreement. ${ }^{95}$

On November 14, 2007, RAM Holdings notified URI of its intention to repudiate performance of the Merger Agreement ${ }^{96}$ and offered either to negotiate a merger on different terms or to make arrangements to pay URI the

\footnotetext{
89. See, e.g., FARNSWORTh, supra note $39, \S 7.9$, at 448-50.

90. United Rentals, 937 A.2d at 814.

91. Id. at 815 .

92. Id. at 814

93. Id. at $814-15$.

94. Id. at 815

95. Id.

96. Id. at 827 . Significantly, Cerberus did not cite any "material adverse change" for backing out of the Merger Agreement, which would have allowed it to back out of the deal without penalty. See id. at 844; see also Dominic Brault, United Rentals: Cerberus Backs Out, Not Us, Seeking Alpha, Nov. 20, 2007, http://seekingalpha.com/article/54801-united-rentals-cerebus-backs-out-not-us. For more on material adverse change (MAC) clauses, see, e.g., Jack Welch \& Suzy Welch, Behind All Those Undone Deals: Nervous Dealmakers Are Trying to Use Loosely Written Escape Clauses to Bail Out, Bus. WK., Dec. 17, 2007, at 84, 84 ("Fast forward, then, to an adverse change — like the subprime crisis — and you understand why so many companies are engaged in legal slugfests over what their MAC clauses technically allow. Sallie Mae and the private equity firm J.C. Flowers could be in court for years, for instance, as could Cerberus and United Rentals.”). See also Joel I. Greenberg \& Julia Haddad, The Material Adverse Change Clause, N.Y.L.J., Apr. 23, 2001, at S5.
} 
$\$ 100$ million termination fee provided for in the Merger Agreement. ${ }^{97}$ URI refused that "offer" and initiated an action for specific performance in the Delaware Court of Chancery under section 9.10 of the Merger Agreement five days after RAM indicated its intention to withdraw from the deal. ${ }^{98}$

The dispute in Cerberus arose from two apparently inconsistent provisions in the Merger Agreement. ${ }^{99}$ Section 9.10 gave the parties the right to seek specific performance upon breach. ${ }^{100}$ The last sentence of this section read: "The provisions of this Section 9.10 shall be subject in all respects to Section 8.2(e) hereof, which Section shall govern the rights and obligations of the parties hereto (and of [Cerberus Partners], the Parent Related Parties, and the Company Related Parties) under the circumstances provided therein." ${ }^{101}$ Article 8 gave either party the right to terminate the Merger Agreement upon breach by the other party and the right to receive a $\$ 100$ million termination fee upon such breach. ${ }^{102}$ The dispute arose because section 8.2(e) of the Merger Agreement, the provision to which the specific performance provision was subject, precluded specific performance. It stated that "in no event shall the Company seek equitable relief or seek to recover any money damages in excess of $[\$ 100,000,000]$ from [RAM Holdings], [RAM Acquisition], [Cerberus Partners] or any Parent Related Party or any of their respective Representatives." 103

URI moved for summary judgment on its complaint for specific performance, and the court denied the motion on the ground that the Merger

97. United Rentals, 937 A.2d at 827 . The collapse of the URI-RAM merger was hardly unique. Private equity buyouts were collapsing regularly in the second half of 2007 because banks had difficulty unloading the huge loans that they had undertaken to finance multi-million dollar private equity deals. See Hallman, supra note 6.

98. United Rentals, 937 A.2d at 827.

99. Id. at 815,817 . I use the word "apparently" because at least one commentator has stated that the provisions in the Merger Agreement were clear. Posting of Jeffrey Lipshaw to Concurring Opinions, http://www.concurringopinions.com/archives/2007/12/the_cerberus_ca.html (Dec. 22, 2007, 09:57 EST) ("I have read the two provisions, and I don't think they are ambiguous. From the standpoint of the logical construction, the contract is doubly clear that the walk-away right dominates over the injunctive right. This, it seems to me, is as close as we come in the law to a semantical paradox, like the Liar's Paradox ('this sentence is false'). The problem is that the grammar and syntax are absolutely clear, but we rebel against the contradictory content."). While Professor Lipshaw is technically correct, this Article takes the perspective that there was no reason for Cerberus and URI to keep the injunctive right in the Merger Agreement because they understood that it could never have effect.

100. United Rentals, 937 A.2d at 815-16.

101. $I d$. at 816 (alteration in original).

102. $I d$.

103. Id. at 817 (second, third, and fourth alterations in original). 
Agreement was sufficiently ambiguous to demand a trial. ${ }^{104}$ The agreement was ambiguous because there were two apparently conflicting provisions on remedies in the event of breach and both parties had a reasonable interpretation of the provisions. ${ }^{105}$ The court found the plaintiff's interpretation - that it had the right to specific performance under section 9.10-reasonable, and while that right was subject to section 8.2(e), the termination fee was not the exclusive provision because (i) the $\$ 100$ million termination fee was the "sole and exclusive remedy" only if the Merger Agreement was terminated (rather than breached) and both parties agreed that the Agreement had not been terminated, and (ii) the outright prohibition on equitable remedies in section 8.2(e) applied only to monetary equitable remedies like rescission and restitution. ${ }^{106}$

The court also found the defendants' interpretation reasonable. ${ }^{107}$ The defendants argued that while section 9.10 gave the plaintiff a right to specific performance, it was "subject to" section 8.2(e), such that "in no event shall [URI] seek equitable relief or seek to recover any money damages in excess of such amount [i.e., the $\$ 100$ million termination fee] from [RAM or Cerberus]. ${ }^{, 108}$ According to the defendants, nothing in that provision suggests, as the plaintiff did, that the termination fee was the exclusive remedy only if the agreement was "terminated." 109 The defendants further argued that Delaware law allowed them to establish the supremacy of one contractual provision over another, such that when terms of one provision are "subject to" the terms of another, the terms of the second provision control even if they nullify the first. ${ }^{110}$ The defendants contended that the plain meaning of "equitable relief" includes specific performance, and that the phrase "in excess of" was in reference to "money damages" - not "equitable relief" and "monetary damages"- so that specific performance was not a type of relief contemplated in the Merger Agreement. ${ }^{111}$

104. Id. at 834

105. Id. at $830-33$.

106. Id. at $830-31$.

107. Id. at 832 .

108. $I d$. at $832-33$ (alterations in original).

109. Id. at 833 .

110. See id. at $833 \mathrm{nn} .106$ \& 107. The defendants relied on Pennsylvania Mutual Life Insurance Co. v. Ogelsby, 695 A.2d 1146, 1150 (Del. 1997) (finding that the phrase "subject to all provisions" had the effect of "subliminat[ing] or trump[ing] other provisions"), and Supermex Trading Co., Ltd. v. Strategic Solutions Group, Inc., Civ. A. No. 16183, 1998 WL 229530 (Del. Ch. May 1, 1998).

111. See United Rentals, 937 A.2d at 833. The relevant provision of section 9.10 provides, "The provisions of this Section 9.10 shall be subject in all respects to Section $8.2(\mathrm{e})$ hereof, which Section shall govern the rights and obligations of the parties hereto (and of the Guarantor, the Parent Related Entities, 
Because Vice Chancellor Chandler found both interpretations reasonable, ${ }^{112}$ he denied URI's motion for summary judgment. ${ }^{113}$ The court held a trial to hear extrinsic evidence. ${ }^{114}$ After the trial, Vice Chancellor Chandler denied URI's request for specific performance. ${ }^{115}$

and the Company Related Parties) under the circumstances provided herein.” Id. at 833 n.105.

112. Id. at 814 .

113. Id. See also United Rentals, Inc. v. RAM Holdings, Inc., Civ. A. No. 3360-CC (Del. Ch. Dec. 13, 2007) (letter order denying motion for summary judgment) ("Having reviewed your briefs and supplemental letters regarding URI's motion for summary judgment, I have concluded that while the question is exceedingly close, summary judgment is not an effective vehicle for deciding the contract issues in dispute in this case. Although I am today denying URI's motion for summary judgment, I will provide more fully my reasons for doing so in the context of the post-trial opinion that will follow promptly after the conclusion of trial on Wednesday, December 19."). The court said the question was "exceedingly close" on the question of summary judgment but, in the end, found that that there were two reasonable interpretations of the apparently inconsistent provisions. United Rentals, 937 A.2d at 814, 830. Because there was not only one reasonable interpretation of the agreement, there was an issue of material fact that required the court to evaluate whether extrinsic evidence and summary judgment were inappropriate. See $i d$. at 834. See also supra note 32. Likewise, the defendants would not have won if they had moved for summary judgment because they could not have satisfied their burden that only their interpretation of the Merger Agreement was reasonable. See United Rentals, 937 A.2d at 832 n.104. While Vice Chancellor Chandler said it "was exceedingly close" whether there was only one reasonable interpretation of the Merger Agreement, see id. at 832, he did not say whose interpretation nearly prevailed. His suggestion that URI would easily have defeated a motion for summary judgment perhaps suggests that URI would have won if he had decided the case on the "four corners" of the Merger Agreement alone. See M\&A Law Prof Blog, http://lawprofessors.typepad.com/mergers/2007/12/the-dog-bites-c.html (Dec. 24, 2007, 05:59 EST) (“The Dog Bites: Coda"). Although Vice Chancellor Chandler stated that he denied URI's motion for summary judgment based on the Merger Agreement alone, see United Rentals, 937 A.2d at 830-34, he did have a preview of some of the extrinsic evidence (in the form of the parties' affidavits and letters) before making his decision. Thus, despite technically applying the four corners rule, we do not know the extent to which he was influenced by extrinsic evidence in denying summary judgment. He also had the luxury when ruling on the summary judgment motion of knowing that he, not the jury, would hear the extrinsic evidence. So there was perhaps little risk and little delay, see infra note 114, of holding a trial.

114. United Rentals, 937 A.2d at 814. How did this all happen so quickly? As one commentator noted:

[a]mong other things, this opinion shows how quickly the Chancery Court, in appropriate circumstances, can schedule a trial and issue a decision involving hundreds of millions of dollars within a few short weeks of the complaint being filed. The complaint in this case was filed, and discovery and a trial took place, as well as a summary judgment motion disposed of (by written decision ... ), and a final post-trial decision issued, all in about 30 days.

Delaware Corporate and Commercial Litigation Blog, http://www.delawarelitigation.com/2007/12/ articles/chancery-court-updates/specific-performance-claim-rejected/index.html(Dec. 24, 2007)("Specific Performance Claim Rejected"). Professor Stephen Bainbridge of the UCLA School of Law suggests that the Delaware Court of Chancery's efficiency and expertise are reasons why Delaware dominates the market for corporate charters. See ProfessorBainbridge.com, http://www.professorbainbridge.com/ professorbainbridgecom/2004/01/delawares-dominance.html (Dec. 26, 2007, 04:53 EST) ("Delaware's Dominance")

115. See United Rentals, 937 A.2d at 845. URI announced on December 24, 2007, that it would not appeal Vice Chancellor Chandler's decision, leaving it with the sole remedy of the reverse break-up fee of 
The extrinsic evidence showed that the apparently inconsistent provisions reflected the parties' dispute during negotiations of the Merger Agreement over whether URI should have the remedy of specific performance if Cerberus backed out of the deal. URI wanted to be able to specifically enforce the Merger Agreement if Cerberus would not close; ${ }^{116}$ Cerberus wanted a $\$ 100$ million walk-away right and for URI to relinquish its right to specific performance. ${ }^{117}$ The initial draft of the Merger Agreement prepared by Simpson, Thacher \& Bartlett LLP (Simpson) contained the specific performance provision, ${ }^{118}$ while the mark-up done by Lowenstein Sandler PC (Lowenstein) deleted that provision. ${ }^{119}$ The parties went back and forth several times, with Simpson including the specific performance provision and Lowenstein deleting it. ${ }^{120}$ RAM and Lowenstein apparently insisted all along in oral conversations with Simpson that the Merger Agreement contain the termination fee as the only remedy for breach. ${ }^{121}$ Supposedly, Eric Swedenburg, Simpson's lead attorney who negotiated the deal, had agreed to that stipulation in a conference call with RAM's attorneys on July 16, 2007, and, because of that and other conversations with RAM's attorneys, knew that Cerberus did not understand the Merger Agreement to provide for a right of specific performance. ${ }^{122}$ Even if URI's attorneys believed it was entitled to specific performance upon breach by Cerberus after that point, this was not communicated to RAM's attorneys. ${ }^{123}$ Whatever their discussion, RAM's attorneys left section 9.10 in the Merger Agreement - the provision that URI contended gave it the right to specific performance. Peter Ehrenberg of Lowenstein, RAM's counsel, testified that he did not know why he left section 9.10 in the Merger Agreement and did not insist on its deletion. ${ }^{124}$

\$100 million. See Press Release, Milbank, Tweed, Hadley \& McCloy, LLP, supra note 17.

116. United Rentals, 937 A.2d at 818.

117. Id. at 818-19. The principal negotiator for URI was Eric Swedenburg of Simpson Thacher \& Bartlett LLP and the principal negotiator for RAM was Peter Ehrenberg of Lowenstein Sandler PC.

118. Id. at $838-40$.

119. Id. at 820 ; see also Hallman, supra note 6.

120. See United Rentals, 937 A.2d at 820-27; see also Hallman, supra note 6.

121. See United Rentals, 937 A.2d at 821-26.

122. See id. at $823-24,843-44$. The parties on that call discussed the July 15,2008 , draft of the Merger Agreement, in which Lowenstein added that section 9.10 was subrogated to section 8.2(e) and "in no event shall company seek equitable relief." Id. at 822 . Swedenburg testified that he was "generally agreeable with the draft 'as written." Id. at 825 .

123. See id. at 839 .

124. See id. at 824 . 
Applying the "forthright negotiator principle," Vice Chancellor Chandler found that RAM prevailed. ${ }^{125}$ While the term "forthright negotiator principle" was new to even seasoned contracts and deal lawyers when Vice Chancellor Chandler used it in Cerberus, ${ }^{126}$ the doctrine itself is found in the Restatement (Second) of Contracts ${ }^{127}$ and at least in certain state's laws. ${ }^{128}$ According to

125. See id. at 836 .

126. See, e.g., Settle It Now, http://www.negotiationlawblog.com/2008/01/articles/negotiation/theforthright-negotiator-principle-who-knew/ (Jan. 5, 2008) ("The Forthright Negotiator Principle? Who Knew?") ("I don't purport to have been around longer than Moses, but I have been pretty actively engaged in the interpretation of contracts since the early 1980 [s]. So it comes as a little bit of a surprise to hear of a contract construction doctrine - even one from out-of-state - that I've never heard of before. Particularly one with as compelling a name as "the forthright negotiator doctrine."'). See also Delaware Corporate and Commercial Litigation Blog, http:/www.delawarelitigation.com/2007/12/articles/chancery-courtupdates/specific-performance-claim-rejected/index.html (Dec. 24, 2007) ("Specific Performance Claim Rejected") ("This opinion is a treasure trove of contract interpretation principles, but here is one that is not seen every day: "the forthright negotiator principle"'); Private Equity Law Review, http:/www.privateequitylawreview.com/2007/12/articles/deal-documents/acquisition-agreement/theforthright-negotiator-Cerberus-and-united-rental/ (Dec. 30, 2007) ("The Forthright Negotiator: Cerberus and United Rental") ("But the court ultimately relied on an interesting though obscure principle of contract interpretation called the "forthright negotiator principle."). No court besides the Delaware Court of Chancery had used the term "forthright negotiator principle" in a decision available on Westlaw before Cerberus, and even the Court of Chancery had used it only twice (in 1996 and 2000) before Cerberus. See U.S. West, Inc. v. Time Warner, Inc., Civ. A. No. 14555, 1996 WL 307445, at *11 (Del. Ch. June 6, 1996) ("Thus, while the subjective understanding of a contracting party is not ordinarily a relevant datum in determining the existence and scope of contractual obligation (such obligations being determined under an 'objective' standard), where ambiguity in contract language is not easily resolvable by extrinsic evidence, it may be necessary for the court, in considering alternative reasonable interpretations of contract language, to resort to evidence of what one side in fact believed the obligation to be, coupled with evidence showing that the other party knew or should have known of such belief. This last principle of contract construction might be called the forthright negotiator principle."); Comrie v. Enterasys Networks, Inc., 837 A.2d 1, 13 (Del. Ch. 2003) (citing West, 1996 WL 307455, at*11).

127. See Restatement (Second) of Contracts $\S 201(2)$ (1981). The Restatement describes the forthright negotiator principle as follows:

Where the parties have attached different meanings to a promise or agreement or a term thereof, it is interpreted in accordance with the meaning attached by one of them if at the time the agreement was made (a) that party did not know of any different meaning attached by the other, and the other knew the meaning attached by the first party; or (b) that party had no reason to know of any different meaning attached by the other, and the other had reason to know the meaning attached by the first party.

Id.

128. See, e.g., Bull Motor Co. v. Murphy, 270 S.W.3d 350, 355 (Ark. Ct. App. 2007) (stating that the prevailing meaning of "new" vehicle not to include a stolen vehicle was consistent with the meaning known to the defendant, and the plaintiff had no reason to know otherwise); Found. Int'l, Inc. v. E.T. Ige Constr., Inc., 78 P.3d 23, 33 (Haw. 2003) ("Assuming, arguendo, that there was some ambiguity or misunderstanding of the contract terms, the ambiguity would be construed against Foundation as a matter of law as it was aware of, or had reason to know of, the State's interpretation of the contract."). And in certain states, such as California, the forthright negotiator doctrine can be gleaned from a combination of statutory and case law. See, e.g., CAL. CIV. CoDE $\S 1649$ (West 1985) ("If the terms of a promise are in any 
Vice Chancellor Chandler, "the forthright negotiator principle provides that, in cases where the extrinsic evidence does not lead to a single, commonly held understanding of a contract's meaning, a court may consider the subjective understanding of one party that has been objectively manifested and is known or should be known by the other party." 129 Vice Chancellor Chandler concluded that in light of the doctrine, "[b]ecause the evidence in this case shows that defendants understood this Agreement to preclude the remedy of specific performance and that plaintiff knew or should have known of this understanding, ... plaintiff has failed to meet its burden and [I] find in favor of defendants." 130 Vice Chancellor Chandler expected URI to be forthright in disclosing the provision it sought in the Merger Agreement. He said, "With respect to URI, I find that even if the Company believed the Agreement preserved a right to specific performance, its attorney Eric Swedenburg categorically failed to communicate that understanding to the defendants during the latter part of the negotiations." 131 In addition, because RAM unequivocally made clear to the attorneys for URI their intention that the exclusive remedy for breach of the Merger Agreement be the $\$ 100$ million termination fee, RAM prevailed. ${ }^{132}$

\section{B. Cerberus Revisited: Getting Lawyers to Write Clearly}

At the core of the "forthright negotiator principle" in Vice Chancellor Chandler's Cerberus decision is that parties should disclose their understanding of the terms they are negotiating to enable them to draft clear and unambiguous agreements, and to avoid the use of ambiguous or inconsistent language to hide disagreement or unresolved terms. As Vice Chancellor Chandler said, "[t]he evidence presented at trial conveyed a deeply flawed negotiation in which both sides failed to clearly and consistently communicate their client's positions." "133 Although URI won, Vice Chancellor Chandler apparently rejected the explanation of Professor Coates in his expert

\footnotetext{
respect ambiguous or uncertain, it must be interpreted in the sense in which the promisor believed, at the time of making it, that the promisee understood it."); De Anza Enters. v. Johnson, 128 Cal. Rptr. 2d 749, 754-55 (Ct. App. 2002) (stating when agreement is ambiguous, the court can look to extrinsic evidence to determine "objective manifestation" of parties' intent).

129. United Rentals, 937 A.2d at 836 . The only authority cited by the court to support this principle is Restatement (Second) of Contracts $\S 201(2)$. Id. at $835 \mathrm{n} .119$.

130. Id. at 813 .

131. Id. at 836 .

132. $I d$.

133. Id.
} 
report that the type of drafting that the parties did in Cerberus (with two provisions, one that made the other superfluous) was acceptable to save time. ${ }^{134}$

Consequently, the core of Vice Chancellor's decision delivers his message to deal lawyers to draft clearly. Professor Larry Ribstein agrees. He writes:

By contrast, Chandler chooses to emphasize a problem that's harder for the parties to fix - the need for ambiguity in order to simplify negotiations. Moreover, Chandler's resolution gives the parties an incentive to clearly communicate their intentions, which is another way to avoid the courts' involvement in sticky disputes like this.

So here we have a lesson for litigators as well as for drafters: if you want to persuade a court, particularly a Delaware judge, consider not only what's reasonable for the given case, but the signals the judge wants to send to future litigants. ${ }^{135}$

The interpretation doctrines considered next are also different means to the same end: signaling to lawyers the importance of drafting without ambiguity.

\section{Contra Proferentem}

Contra proferentem is a rule of interpretation that provides that if a contract is ambiguous on its face, it is interpreted against the drafting party. ${ }^{136}$ The reasoning behind this doctrine is that the party drafting the contract is often in a better position to write clear language to avoid uncertainty. ${ }^{137}$ Where

134. See Coates Expert Report, supra note 24.

135. Ideoblog, http://busmovie.typepad.com/ideoblog/2007/12/Cerberus-uri-wh.html(Dec. 21, 2007, 19:22 EST) ("Cerberus-URI: What to Do About Sloppy Drafting").

136. See Lord, supra note 40, $\$ 32: 12$, at 471-80. See also Restatement (SeCond) of Contracts $\S 206$ (1981) ("In choosing among the reasonable meanings of a promise or agreement or a term thereof, that meaning is generally preferred which operates against the party who supplies the words or from whom a writing otherwise proceeds."). The doctrine applies only if the agreement is facially ambiguous. As one commentator noted, "[a]s potential ambiguities spring to mind, bear in mind that in order to apply contra proferentem, the language must be ambiguous 'as applied' to the factual case at hand." Michelle E. Boardman, Contra Proferentem: The Allure of Ambiguous Boilerplate, 104 Мich. L. REv. 1105, 1122 (2006). One commentator believes that the doctrine itself as used in insurance cases is ambiguous and calls for reform. See Bradley D. Liggett, Comment, Contra Applicantem or Contra Proferentem Applicatio: The Need for Clarification of the Doctrine of Contra Proferentem in the Context of Insured-Created Ambiguities in Insurance Applications, 2008 BYU L. Rev. 211, 215-19.

137. See Posner, supra note 19, at 1608; Francis Bacon, The Elements of the Common Law of England, in 3 THE Works OF FranCIS BACON 225, 225 (1857) ("[Contra proferentem] is a schoolmaster of wisdom and diligence in making men watchful of their own business."). See also Penn. Mut. Life Ins. Co. v. Oglesby, 695 A.2d 1146, 1150 (Del. 1997) ("[I]t is incumbent on the dominant party to make terms clear."). 
both parties have relatively equal bargaining power or are sophisticated or represented by counsel, the doctrine usually does not apply because both parties have the opportunity to review the agreement to prevent ambiguity. ${ }^{138}$

In Klapp v. United Insurance Group Agency, Inc., ${ }^{139}$ the court applied contra proferentem in hearing an appeal of a dispute that arose out of inconsistencies between an insurance agent's contract with his former employer (the Agent's Agreement) and the Agent's Manual that was incorporated into the contract. The plaintiff, an insurance agent who worked for the defendant, sued his former employer for renewal commissions that he argued had vested at the time of his retirement. ${ }^{140}$ The schedule in the Agent's Agreement vested renewal commissions after two years of an agent's service, and the plaintiff's benefits were fully vested because he left the company after seven years. ${ }^{141}$ The Agent's Manual provided, "Retirement is understood to be disengagement from the insurance industry. Vestment for retirement is age 65 or 10 years of service, whichever is later." "142 The defendant argued that the contract was not ambiguous; the plaintiff had not "retired" and thus his commissions had not vested because he neither worked for the insurance company for ten years nor reached the age of sixty-five when he left the company. ${ }^{143}$ The plaintiff, however, argued that the contract was ambiguous and should be subject to interpretation by a jury. ${ }^{144}$

138. See, e.g., Beanstalk Group, Inc. v. AM Gen. Corp., 283 F.3d 856, 858 (7th Cir. 2002) ("The agreement was drafted by Beanstalk, but this fact has little interpretive significance since AM General is a commercially sophisticated party represented by counsel. Most courts now agree with the exception to the principle that the contracts are to be construed against the party who drafted it."); Shelby Co. State Bank v. Van Diest Supply Co., 303 F.3d 832, 838 (7th Cir. 2002) ("Not only should the drafter be penalized by bearing the costs ex post of having cut corners ex ante, the penalty of interpretation against the drafter also aims to avoid overbearing behavior between contracting parties where the drafter, often the one in the better bargaining position, tries to pull a fast one over the party who can merely accept or reject the contract as a whole.”); First State Underwriters Agency of New England Reinsurance Corp. v. Travelers Ins. Corp., 803 F.2d 1308, 1311-12 (3d Cir. 1986) ("If an ambiguity does exist and if the insurer wrote the policy or is in a stronger bargaining position than the insured, the ambiguity is generally resolved in favor of the insured and against the insurer. However, the principle that ambiguities in policies should be strictly construed against the insurer does not control the situation where large corporations, advised by counsel and having equal bargaining power, are the parties to a negotiated policy.").

139. 663 N.W.2d 447, 451-52, 454-59 (Mich. 2003).

140. Id. at 449 .

141. Id. at 451 .

142. Id. at 452 .

143. Id.

144. Id. The trial court and the jury sided with the plaintiff, the court of appeals reversed, and the Michigan Supreme Court reinstated the jury's decision. Id. at 449-50. 
The trial court left it to the jury to decide which of the inconsistent provisions governed. ${ }^{145}$ The Michigan Supreme Court found that, as often appears to be the case with contractual inconsistencies, interpretation could not be resolved from the "four corners" of the document and thus was an issue for the finder of fact - in this case, a jury and not the judge. ${ }^{146}$ The court also found that the trial court's instruction to the jury to construe all ambiguities against the drafter was proper. ${ }^{147}$ In his concurrence, Justice Weaver explained two rationales for the doctrine of contra proferentem as applied by the Michigan Supreme Court. First, "the rule provides a strong incentive for a party drafting a contract to use clear and unambiguous language." 148 The rule, like Vice Chancellor Chandler's opinion in Cerberus, discourages lawyers from using ambiguous language as a shortcut to reach an agreement. Second, Justice Weaver writes:

[T] he use of extrinsic evidence in circumstances involving ambiguity could be destabilizing to contractual relations and require more involved litigation by allowing

145. $I d$.

146. Id. at 453-54. The issue is not whether interpretation raises a question of fact or law. Interpretation is a question of fact, as it involves a determination of the meaning that the parties attached to words in an agreement. See Farnsworth, supra note 39, § 7.14, at 476. Rather, the issue is whether interpretation is for the court or the jury. The traditional view, rejected by the Michigan Supreme Court in Klapp, is that interpretation is for the judge. See Klapp, 663 N.W.2d at 453-54; Timothy J. Malloy \& Patrick V. Bradley, Claim Construction: A Plea for Deference, 7 Sedona Conf. J. 191, 193-94 (2006). The Restatement (Second) of Contracts also rejects the traditional approach and states that interpretation is a matter for the jury when it depends on "the credibility of extrinsic evidence or on a choice among reasonable inferences to be drawn from intrinsic evidence." Restatement (Second) of Contracts $\S 212(2)$ (1981). However, when a court can interpret a contract from the "four corners" of the document itself, interpretation is solely a matter for the court. See, e.g., Mo. Pac. R.R. Co. v. Kan. Gas \& Elec. Co., 862 F.2d 796, 799 (10th Cir. 1988) (stating when the court can interpret ambiguous contract without extrinsic evidence, interpretation is a judicial function). The question of whether a written document is ambiguous and, therefore, whether extrinsic evidence should be admitted is always a question of law. See id.

147. Klapp, 663 N.W.2d at 459. The majority and concurrence disagreed over whether contra proferentem applied only in the case of a tie or whether it was a primary doctrine of construction. Compare $i d$. at 459 ("Although the trial court correctly instructed the jury that it could consider relevant extrinsic evidence and that any ambiguities should be construed against the drafter pursuant to the rule of contra proferentem, the trial court failed to inform the jury that it could only apply the rule of contra proferentem if it was unable to discern the parties' intent from the extrinsic evidence."), with id. at 460 (Weaver, J., concurring) ("I would hold that when a contract is drafted entirely by one party, without any bilateral negotiations, the rule that a contract is to be strictly construed against its drafter should be applied as the primary rule of construction, not as a last resort, and extrinsic evidence is not admissible to clarify ambiguity in the contract."). I doubt this difference is more than theoretical. On some level, the finder of fact, the jury in this case, is deciding how blameworthy the drafting party is for writing unclear language. That question is always going to be a matter of degree no matter what the rule is.

148. Id. at 461 (Weaver, J., concurring). 
parties to use assertions of oral understandings and examples of past behavior rather than relying on a written contract with the understanding that any ambiguity should be construed against its drafter. ${ }^{149}$

As noted by Justice Weaver, in the rush to complete a deal, sloppy or deliberate inconsistencies can interfere with, rather than facilitate, contractual relations.

In McNeely v. Claremont Management Co.,${ }^{150}$ the court also applied contra proferentem in response to a dispute that arose as to whether a printed or handwritten provision in the contract between a homebuilder and buyer controlled. ${ }^{151}$ The defendant built a house that was purchased by the plaintiffs, and the defendant gave the plaintiffs a written warranty that the house was in substantial conformity with the plans and specifications approved by the Federal Housing Commissioner. ${ }^{152}$ The contract stated that the plaintiffs had to give defendants notice of any breach of warranty

within one year from the date of original conveyance of title to such Purchaser(s) or the date of initial occupancy of the dwelling, whichever first occurs: Provided further, however, that in the event the Purchaser(s) acquired title to the captioned property prior to the completion of construction of the dwelling thereon, such notice of nonconformity to the Warrantor may be given at any time or times within one year from the date of completion or initial occupancy of such dwelling, whichever first occurs. ${ }^{153}$

Yet, the contract also contained this provision:

Notice to Purchaser: Any Notice of Nonconformity Must Be Delivered to the Warrantor No Later than January 6, 1957. (Warrantor shall insert date one year from initial occupancy, date of conveyance of title or date of completion, whichever event is applicable. $)^{154}$

149. Id.

150. 27 Cal. Rptr. 87, 89 (Ct. App. 1962).

151. But cf. Joseph Francese, Inc. v. Enlarged City Sch. Dist. of Troy, 693 N.Y.S.2d 280, 282 (App. Div. 1999) ("The parties' written modification to the contract, in the form of deleting the entire arbitration section, reflected their agreement that arbitration would not be available for the resolution of disputes. By virtue of this written modification, any undeleted references to arbitration in the printed clauses of the contract were rendered meaningless.”); Otto Interiors, Inc. v. Nestor, 763 N.Y.S.2d 439, 441 (Civ. Ct. 2003) (holding that, where form was generated from computer software, information inputted by user in computer program is a typewritten addition that should be given greater effect).

152. McNeely, 27 Cal. Rptr. at 88.

153. $I d$.

154. Id. (capitalization altered). The date January 6,1957 , was handwritten into the contract by the defendant. Id. at 89. 
The plaintiffs moved into the house on March 16, 1955, and took title on January $12,1956 .{ }^{155}$ The plaintiffs gave notice of certain breaches on January 14,1956 , and those were addressed by the defendant. ${ }^{156}$ At issue were breaches that the plaintiff reported on October 4, $1956 .{ }^{157}$

The court found that even though the plaintiff gave notice more than one year after it began occupying the premises, the January 6, 1957, date prevailed. ${ }^{158}$ The court held that the specific provision (the date entered by the defendant) prevailed over the general provision and the handwritten provision prevailed over the printed provision. ${ }^{159}$ This makes sense because the handwritten provision was inserted later into the contract and offered the best chance to avert uncertainty. ${ }^{160}$ In addition, the court applied the doctrine of contra proferentem and found that "since defendant is the party who prepared the warranty, it must bow to the decisive rule that the instrument must be interpreted most strongly against it since it is the party who caused the uncertainty to exist." 161 The court's reasoning for applying the rule is instructive; because the defendant could have avoided the uncertainty by making the printed and handwritten terms consistent, its interpretation should not prevail.

\section{Four Corners Rule}

The "four corners rule" is that a court should determine whether a contract is ambiguous from the "four corners" of the document, without considering extrinsic evidence. ${ }^{162}$ This is the rule that the court purportedly applied in Cerberus. ${ }^{163}$ The problem is that ambiguity is not a black and white

155. Id. at 88 .

156. Id.

157. See id.

158. Id. at 89 .

159. Id. The court stated, "Also, where the provisions of such an instrument are inconsistent, the written or typewritten parts control the printed parts." Id.

160. Although this Article does not discuss this particular canon of construction at length, it is consistent with the idea of writing clear contracts because the drafter of the typewritten or printed term could have presumably prevented the ambiguity.

161. McNeely, 27 Cal. Rptr. at 89.

162. See supra note 32. See also, e.g., W.W.W. Assocs., Inc. v. Giancontieri, 566 N.E.2d 639, 642 (N.Y. 1990) (stating "extrinsic evidence should [not] be considered in order to create an ambiguity in the agreement").

163. See United Rentals, Inc. v. RAM Holdings, Inc., 937 A.2d 810, 830-34 (Del. Ch. 2007); see also supra note 113 . 
issue, and a court is at risk of getting the "incorrect" answer, especially when parties deliberately introduce ambiguity into contracts.

In Hardin v. Dimension Lumber Co., ${ }^{164}$ the plaintiffs sold to the defendant all the timber that could be cut from a particular tract of land for $\$ 1.25$ per thousand feet of timber cut; yet, the contract also provided "that the entire sale and purchase price of said timber is $\$ 1400.00$." The defendant paid $\$ 1,400$ under the contract and thought it owed no more. ${ }^{165}$ The plaintiffs sought a balance of $\$ 3,956$, calculating the balance due based on $\$ 1.25$ per thousand feet that the defendant cut and removed from their land. ${ }^{166}$ The dispute arose about the contractual inconsistency over how much the defendant owed.

The court interpreted the contract to mean that the plaintiffs owed the defendant $\$ 1.25$ per thousand feet of timber cut, up to a maximum of $\$ 1,400 .{ }^{167}$ The court did not look beyond the "four corners" of the contract to determine if the contract was ambiguous. ${ }^{168}$ The court noted that, if possible, "inconsistent" terms should be interpreted as consistent with each other so that both inconsistent terms have effect. ${ }^{169}$ As the court stated, "[i]t is a rule of universal application that a contract must be construed as a whole and effect must be given, if possible, to every word and phrase in it. This is one of the primary rules which is applicable not only to written contracts, but to writings generally." ${ }^{\prime 170}$ Under this application of the four corners rule, a court can interpret even facial ambiguity, such as inconsistent terms or provisions, out of a contract. ${ }^{171}$

164. Hardin v. Dimension Lumber Co., 13 P.2d 602, 602 (Or. 1932).

165. Id. at 603 .

166. $I d$. The jury found that the defendant owed the amount that the plaintiffs alleged was due and the Oregon Supreme Court reversed. Id. at 604.

167. Id. In passing, the court quoted a rule laid down by William Blackstone. Blackstone had articulated the following rule: "In a deed if there be two clauses so totally repugnant to each other that they cannot stand together, the first shall be received and the latter rejected." Id. at 603 (quoting WiLLIAM Blackstone, 2 Commentaries *381). About a century ago, the Oregon Supreme Court articulated a similar rule with regard to contracts - if in a contract two clauses are inconsistent, the first should govern - but with the limitation that the rule should apply only if consistent with other principles of interpretation. See Gaines v. Vandecar, 115 P. 721, 722 (Or. 1911); Lachmund v. Lope Sing, 102 P. 598, 600 (Or. 1909). Such a rule is artificial and does not have any value.

168. See Hardin, 13 P.2d at 604 .

169. Id. at 603-04.

170. Id. See also Purcell-Murray Co. v. Wolf Range Co., No. A094225, 2002 WL 853542, at*4 (Cal. Ct. App. May 6, 2002) (finding the contract ambiguous and then noting that "[o]ur task when faced with such contradictory and inconsistent provisions of a contract is to reconcile them, if possible, in such a way that gives effect to the main purpose of the contract and avoids rendering some parts of the contract inoperative or meaningless").

171. It appears that the court took this approach and perhaps suggested that extrinsic evidence is never permissible to interpret a contract. Hardin, 13 P.2d at 604 ("It is also a universal rule of law that the 
If Vice Chancellor Chandler had followed this "universal" rule of application in Cerberus, URI likely would have prevailed. Under this rule, URI and Cerberus would have included the injunctive right only if they intended for it to have effect in certain cases and, therefore, Vice Chancellor Chandler could have found the termination fee and specific performance as alternatives for URI when Cerberus backed out of the agreement. Such a result would have made more sense if the court had confidence that the parties had expressed their intentions clearly. However, sloppy drafting and deliberate ambiguity also explain inconsistent provisions, where we turn next.

\section{Why Do Lawyers Draft Inconsistent Terms?}

Oftentimes, there is a simple misunderstanding that creates ambiguous contract language. ${ }^{172}$ Additionally, many lawyers do a poor job of drafting contract language that is clear. ${ }^{173}$ While unintentional sloppiness or clumsiness is a common cause of ambiguous and other unclear language, ${ }^{174}$ some ambiguity, even in the case of inconsistent terms, is deliberate, as Cerberus

obligations of the parties to a written contract must be gathered from the four corners of the instrument, and that no part of a contract can be ignored as inconsistent with the general intent, if by any reasonable method of interpretation effect can be given to such part of the contract as well as to the remaining parts thereof.").

172. Judge Posner writes, "But it would be a mistake for courts to take the position that any ambiguity in a contract must be the product of a culpable mistake by one or both of the parties - that the judicial function in contract law is to punish parties who do not make their agreement clear." Posner, supra note 19 , at 1583 .

173. See, e.g., Macaulay, Kidwell \& Whitford, supra note 20, at 243. Judge Posner notes that clumsiness in contract drafting is one cause of interpretation problems that arise in contract litigation. See Posner, supra note 19, at 1582. Of course, some lawyers deliberately use unclear language. See infra note 175.

174. For a critique of this category of sloppiness as a cause of contractual ambiguity, see Posting of Jeffrey Lipshaw to Concurring Opinions, http://www.concurringopinions.com/archives/2007/12/ the_cerberus_ca.html (Dec. 22, 2007, 09:57 EST) ("Perhaps it is because I have actually been in the shoes of an M\&A lawyer trying to craft a linguistic solution, or have been the client of M\&A lawyers trying to craft linguistic solutions for me, that I chuckle at the charges of 'sloppy drafting' as though lawyers have the absolute power (a reductive, rational, scientific, but unrealistic assumption) to control all outcomes through language. One of my rules of thumb in negotiating language was to change as little as possible to achieve the desired outcome. That's an art, not a science, and Cerberus' lawyer's judgment ultimately bore out in this case. Who knows what would have happened if he tried to make the change by deleting rather than trumping?"). 
illustrates. ${ }^{175}$ Before discussing deliberate ambiguity, we will look at sloppiness in contractual drafting as a source of ambiguity.

\section{A. Sloppiness}

Lawyers and judges have long bemoaned sloppiness in contracts. ${ }^{176}$ According to a study of 1996 collective bargaining agreements by James Suchan and Clyde Scott, in which three formulas were used to measure the understandability of documents, ${ }^{177} 95$ to 99 percent were "difficult" or "very difficult" to understand. ${ }^{178}$ One index they used revealed that "the rank and file would need more than 18 years of education - a college degree plus two years of graduate school-to unscramble a typical union-management

175. A pair of commentators called this practice "planned obfuscation." See James Suchan \& Clyde Scott, Unclear Contract Language and Its Effect on Corporate Culture, 29 Bus. HoRIzons 20, 23 (1986) ("To avoid long squabbles that would slow down the negotiating process, negotiators may deliberately use unclear language. Management or labor may want to avoid being pinned down on a contract issue or may feel that agreeing to something is better than not agreeing at all. Consequently, imprecise language may be used to draft a contract provision. Negotiators know that arbitrators can ultimately decide what the provision means and how it will be applied."); see also United Rentals, Inc. v. RAM Holdings, Inc., 937 A.2d 810, 845 (Del. Ch. 2007) ("[I]n fact, parties often riddle their agreements with a certain amount of ambiguity in order to reach a compromise."); Posner, supra note 19, at 1583 ("Deliberate ambiguity may be a necessary condition of making the contract; the parties may be unable to agree on certain points yet be content to take their chances on being able to resolve them, with or without judicial intervention, should the need arise."). Vice Chancellor Chandler and Judge Posner are likely using "ambiguity" as a synonym for "unclear," see supra notes 43-44 and accompanying text, and not in accordance with the definition given in Part I.D of this Article. Ironically, this misuse itself creates ambiguity. But this Article defines "ambiguity" as it does to differentiate unclear language that might be desirable (open contracts, incompleteness, and vagueness), see supra note 28 , from ambiguous language that is not desirable.

176. See, e.g., Murphree v. W.W. Transp., 797 So. 2d 268, 277 (Miss. Ct. App. 2001) ("Some sloppiness in general language cannot override the specific reference to this corporation"); Symposium, Alternative Dispute Resolution in the Entertainment Industry, 4 CARdozo ONLINE J. CONFLICT Resol. 1 (2002) ("Just a quick comment. With respect to arbitration clauses in a contract, it is important that they are to be drafted carefully if they are going to be put in. I see so many contracts coming across my desk where there is sloppiness in the provisions in the agreement. The arbitration clause, to the extent that it is in there, has problems as well. So if you are going to have, and that is what I really think we are talking about with respect to the ethical obligation, if you made a conscious and careful decision with respect to a transaction that you want to contain a mediation or arbitration clause, it is not just one boilerplate clause. There are very different ways you can structure it. You can reserve rights. You can have certain rules apply, certain rules not apply; who is the mediator; how do you pick the mediator; are there any kind of limited subsequent rights to challenge the award? All of these things need to be carefully thought through, and so I think that is a really important issue to be thought through in terms of drafting.").

177. See Suchan \& Scott, supra note 175, at 21-22. The three indices they used to evaluate the documents measured sentence and clause length and the number of single syllable and polysyllabic words. Id.

178. Id. at 22 . 
agreement." ${ }^{179}$ Suchan and Scott posit that these agreements are perhaps unclear because attorneys copy stock clauses from formbooks - or from other agreements - so the problem keeps repeating and attorneys "inhabit a semantic world different from that of the rank and file's." ${ }^{80}$

One cause of sloppiness and ambiguity is unclear thinking, or lawyers who are not sure of what they are trying to say. Suchan and Scott call this "unplanned fuzziness":

Agreements can also be difficult to read because union and management may be uncertain what they are trying to say. Contracts written during severe time constraints - during round-the-clock negotiations just prior to the expiration of an agreement, for example - will reflect the rushed and confused thinking of fatigued negotiators struggling to [reach] an agreement and thus avert a possible strike. Needless-to-say, confused thinking often results in garbled, difficult-to-understand clauses. ${ }^{181}$

Of course, this is not much different than what Professor Coates described in his expert report in Cerberus. He discussed that parties in M\&A transactions often do not review every provision of an agreement carefully. ${ }^{182}$ One likely cause of lawyers drafting ambiguous provisions is that they want to save time and expense. Coates writes:

One of the ways that parties economize on time and costs is not to attempt to review every provision of every related agreement every time a new change is made, particularly when documents are in the final stages of negotiation. Rather they rely on succinct but legal terms of art to achieve what is, in essence, "editing" of the entirety of a document with minimal change. Among the terms of art customarily relied upon are phrases such as "subject to" and "notwithstanding." These phrases allow the parties to specify that one phrase or provision will take precedence over others, and thus avoid the need to attempt to synthesize every provision of every related agreement that is or may be partly or wholly in conflict with the provision in question. ${ }^{183}$

179. Id.

180. See id. at 22-23. Germans, by contrast, avoid much of the legalese of American contracts. See Claire A. Hill \& Christopher King, How Do German Contracts Do As Much with Fewer Words?, 79 CHI.Kent L. Rev. 889, 889 (2004). Germans also write shorter contracts, but this Article does not go as far as suggesting that Americans write shorter contracts at the expense of not getting the deals that they want. See id. at 891 .

181. Suchan \& Scott, supra note 175 , at 23.

182. See Coates Expert Report, supra note 24, at 10-11.

183. Id. One contracts expert, Kenneth Adams, calls the current process of drafting business agreements dysfunctional. See supra note 21. 


\section{B. Conscious Ambiguity}

Interestingly, Coates appears to condone an inconsistency even if the parties know about it. ${ }^{184}$ Of course, he was testifying for his client Cerberus, which likely knew that the remedies provisions in the Merger Agreement were inconsistent. Professor Steven Davidoff, frequent M\&A legal commentator, summarized the negotiation process in Cerberus:

I think we now have a confident view of how the negotiation occurred. Throughout the contract negotiation process the Cerberus side made it clear at all times that its contracting policy did not permit it to allow the Seller a specific performance remedy and the URI side pushed at all times to get them on the hook if the financing was available. URI tried to do that that in many ways on all three agreements (merger agreement, limited guarantee, equity commitment letter) without making all the progress they wanted.

The Cerberus legal team was under strict orders to keep the out clear to their side; Simpson [Thacher \& Bartlett LLP] via [Eric] Swedenburg ultimately was under pressure to get Cerberus signed up as best he could. I believe he was lucky that the other side allowed 9.10 to stay in subject to 8.2(e) even if 8.2(e)'s final sentence added by [Peter] Ehrenberg reduced URI's optionality to force it to accept the payment of the reverse termination fee in a Cerberus breach. And, think about it, one can reasonably conclude from the evidence that URI and Simpson adopted this strategy deliberately-if so, they did a fantastic job given their hand even if Swedenburg was found not to be a forthright negotiator (there are other explanations here but for now let's take this one). According to Chandler, he almost succeeded and no doubt Chandler realized the higher probabilities of being reversed on summary judgment versus a trial and that must have factored into his thinking to deny summary judgment to URI. Sloppy drafting helped URI much more than Cerberus. At the time the deal was executed, it may be that URI took a calculated risk that Cerberus wouldn't take the reputational hit of walking and (unfortunately) was wrong. ${ }^{185}$

The negotiation process leading up to the Merger Agreement in Cerberus shows that URI's attorneys knew of the ambiguity in the Merger Agreement,

184. See Coates Expert Report, supra note 24, at 12 ("Having habituated themselves to these drafting techniques, deal attorneys rely on them even when a given potential conflict in contract provisions is known and clear, or when it would not be particularly expensive or time-consuming to redraft other potentially conflicting provisions in the contract."). While there might be some difference between "knowing" and "deliberate" ambiguity in some cases, especially where one party to the contract has less control over the language used (e.g., in a form contract where the consumer knows of an ambiguity but lacks the power to negotiate over language), that distinction is of little difference in a case like Cerberus, where both parties (and their lawyers) had enough leverage to negotiate over the language used in the agreement. This Article, in places, uses the phrase "conscious ambiguity" to refer to ambiguity that is either intentional or knowing.

185. M\&ALaw Prof Blog, http://lawprofessors.typepad.com/mergers/2007/12/uriCerberus-the.html (Dec. 27, 2007) (“URI/Cerberus: The Final Word”). For a similar account of the negotiations, see Hallman, supra note 6 . 
and that an injunctive right (apparently inconsistent with, and negated by, the walk-away right) was the best that URI could get because Cerberus did not want the equitable option in the contract. Cerberus's attorneys likely knew of the apparent inconsistency as well, but thought that making the injunctive right "subject to" the walk-away right was enough to protect their client from specific performance. ${ }^{186}$ Even Vice Chancellor Chandler suggested that the parties might have deliberately drafted inconsistent provisions when he said:

As with many contract disputes, hindsight affords the Court a perspective from which it is clear that this case could have been avoided: if Cerberus had simply deleted section 9.10(b), the contract would not be ambiguous, and URI would not have filed this suit. The law of contracts, however, does not require parties to choose optimally clear language; in fact, parties often riddle their agreements with a certain amount of ambiguity in order to reach a compromise. ${ }^{187}$

By not insisting on eliminating the injunctive right from the Merger Agreement altogether, Cerberus cost itself a lawsuit and, more significantly, risked having to complete the merger with URI.

Even though URI lost, it did preserve its litigation option by getting Cerberus to agree to keep the specific performance provision in the Merger Agreement. URI could have won on its gamble had the Court of Chancery specifically enforced the Agreement. Was the deliberate inconsistency in the Merger Agreement then good strategy by URI? Perhaps as a matter of gamesmanship, but Vice Chancellor Chandler did not approve, ${ }^{188}$ and Part IV

186. According to one account of the deal, "[Kevin] Rinker, [a] Debevoise [\& Plimpton] partner [who does private equity deals], says he guesses Ehrenberg was probably trying to tread lightly: 'He used the 'subject to' trick to knock out a conflicting provision and went on his merry way." Hallman, supra note 6. Even if Cerberus's attorneys were not aware of the full risk of being subject to the injunctive right, they were likely aware of the potential inconsistency. Hallman, a reporter who interviewed private equity deal lawyers and contract drafting experts about the case, describes, "Kevin Rinker, a Debevoise \& Plimpton partner who practices in the area of private equity and who presented a case study of the deal to his fellow partners, agrees with this analysis. From the testimony, he says, it appears Ehrenberg won a point during the negotiations but then failed to clearly articulate it in the contract." Kenneth Adams, a former Jones Day and Winston \& Strawn lawyer who now advises law firms on contract matters, goes a step further. "It was a major failure of drafting," he says. "What happens if and when someone walks is a do-not-pass-go issue." $I d$. Hallman also writes, "Lawyers familiar with the deal say they believe the United Rentals case offers a glimpse into a little-noticed but common practice: Deal lawyers often agree to contracts with ambiguous language for the sake of compromise. Whether this is what happened here, or whether Ehrenberg simply made a mistake, is unknown, but the lesson is clear. 'Notwithstanding the pressures of the deal, you really have to think hard about every provision,' [Kevin Rinker, a Debevoise \& Plimpton partner who practices in the area of private equity,] says." Id.

187. United Rentals, Inc. v. RAM Holdings, Inc., 937 A.2d 810, 845 (Del. Ch. 2007).

188. Id. at 836 . 
criticizes the deliberate use of language to create an inconsistency (even when used in an effort "to get the deal done").

\section{The Case Against Conscious Ambiguity}

It is a long-heeded cannon that lawyers have an obligation to be zealous advocates for their clients. ${ }^{189}$ Therefore, why should a lawyer not introduce ambiguity into an agreement if it gives the client additional leverage in the course of performance and a better litigation strategy should the deal break up? The answer is found in contract theory, as well as the lawyer's professional obligations to her client and to the integrity of the profession.

\section{A. Consent}

The overriding question of contract law is when the state should use its power to enforce a promise. ${ }^{190}$ A goal of contract law suggested by courts and commentators is to resolve interpretation and implication problems by finding the "correct answer" or the solution that the parties intended to enact. ${ }^{191}$ In the first instance, the "correct answer" that the parties intended is the objective manifestation of their intentions. ${ }^{192}$ "Intention, however, is determined objectively and prospectively: A party is taken to mean what its contract partner could plausibly believe it meant when the parties contracted. ${ }^{" 193}$ But if these intentions conflict, it becomes more difficult for the court to interpret the contract consistent with the objective manifestations of the parties.

A consent theory of contract law explains how courts have interpreted contracts and shows the shortcomings of courts condoning ambiguous drafting as an effective bargaining strategy. Under a consent theory of contract law, state coercion against the parties must be justified, and what the parties agreed

189. See, e.g., M. Neil Browne, Carrie L. Williamson \& Linda R. Barkacs, The Purported Rigidity of an Attorney's Personality: Can Legal Ethics Be Acquired?, 30 J. Legal Prof. 55, 69 (2006) (noting the traditional role of lawyer as "zealous advocate"). See also Michael H. Rubin, The Ethical Utah Lawyer: What Are the Limits in Negotiation?, 21 UTAн B.J. 15, 15 (2008) ("For over two hundred years, lawyers have been encouraged to be 'zealous advocates' of their clients' interests."). The requirement of a lawyer being a zealous advocate has not been in the national lawyers' codes since 1983. See id.

190. See, e.g., Barnett, supra note 38, at 269 ("We look to legal theory to tell us when the use of legal force against an individual is morally justified. We look to contract theory, in particular, to tell us which interpersonal commitments the law ought to enforce." (footnote omitted)).

191. See Schwartz \& Scott, supra note 30, at 558, 569.

192. See id. at 569.

193. $I d$. 
to do (objectively manifested) is sufficient justification. As Professor Barnett described, "[p]roperly understood, contract law is that part of a system of entitlements that identifies those circumstances in which entitlements are validly transferred from person to person by their consent. Consent is the moral component that distinguishes valid from invalid transfers of alienable rights. ${ }^{194}$ Because it was unclear in Cerberus to what the parties had assented from the written contract itself, it was consistent with a consent theory for the court to look at extrinsic evidence to determine to what, if anything, they had agreed. ${ }^{195}$

Interpreting inconsistent contract provisions requires subjectivity - and it is this subjectivity that often undermines the identification process. ${ }^{196}$ Barnett explains how parties must be able to ascertain a contract's boundaries clearly:

\begin{abstract}
In contract law, this informational or "boundary defining" requirement means that an assent to alienate rights must be manifested in some manner by one party to the other to serve as a criterion of enforcement. Without a manifestation of assent that is accessible to all affected parties, that aspect of a system of entitlements that governs transfers of rights will fail to achieve its main function. At the time of the transaction, it will have failed to identify clearly and communicate to both parties (and to third parties) the rightful boundaries that must be respected. Without such communication, parties to a transaction (and third parties) cannot accurately ascertain what constitutes rightful conduct and what constitutes a commitment on which they can rely. Disputes that might otherwise have been avoided will occur, and the attendant uncertainties of the transfer process will discourage reliance. ${ }^{197}$
\end{abstract}

Despite the conventional wisdom that ambiguity enables parties "to get deals done," the uncertainty that ambiguity creates has the potential to decrease rather than increase contractual reliance. The Merger Agreement in Cerberus left URI, Cerberus, and any third party who relied on it unable to know what the parties' respective rights were.

194. See Barnett, supra note 38 , at 270 . Of course, if the ambiguity is material, there might not be an agreement in the first place.

195. Cf. id. at 308 ("This also explains why the misuse of a particular term by party A who was unaware of its ordinary meaning would not bind $\mathrm{A}$ if it could be shown that B, the other party, was made aware of this mistake by the circumstances of the transaction. Proof of this occurrence would show that the normal boundary-defining function of an objective approach designed to protect parties in B's position had been satisfied by B's actual knowledge of A's meaning. A consent theory, therefore, explains both why parties are free to shift away from the ordinary meanings of words or deeds either intentionally or inadvertently, and why, if a shift by both cannot be shown, the ordinary or 'objective' meaning will govern.") (footnote omitted).

196. See supra note 88 .

197. See Barnett, supra note 38 , at 302. 
The primary alternative to autonomy-based theories is standard-based theories, the primary one of which is efficiency. ${ }^{198}$ Under an efficiency theory, parties contract to maximize net social welfare or wealth (somehow defined).${ }^{199}$ The primary problem with an economics approach to contract law is that it does not explain adequately which contracts are enforceable and which are not; it does not explain why only voluntary promises are enforced. ${ }^{200}$ There was no sign in Cerberus or the other ambiguity cases discussed in this Article that an efficiency theory helped courts get at the "correct answer."

\section{B. Professional Obligations}

This subpart discusses why an attorney's obligations to his or her client and the profession could require him or her to refrain from consciously including ambiguous contract language without disclosing it to the other contracting party.

\section{Duty to the Client}

Model Rule 1.1 requires that "[a] lawyer shall provide competent representation to a client. Competent representation requires the legal knowledge, skill, thoroughness and preparation reasonably necessary for the representation." ${ }^{201}$ Lawyers should avoid conscious ambiguity if it interferes with their duty of competent representation because the client would be better served by clear language. ${ }^{202}$

198. See, e.g., id. at 277-78.

199. See, e.g., David Dana \& Susan P. Koniak, Bargaining in the Shadow of Democracy, 148 U. PA. L. Rev. 473, 546 (1999).

200. See, e.g., Barnett, supra note 38, at 278-79. See also Eric A. Posner, Economic Analysis of Contract Law After Three Decades: Success or Failure?, 112 YALE L.J. 829, 830 (2003) ("For these reasons, I will argue that economic analysis has failed to produce an 'economic theory' of contract law, and does not seem likely to be able to do so. By this, I mean that the economic approach does not explain the current system of contract law, nor does it provide a solid basis for criticizing and reforming contract law.").

201. Model Rules of Prof'L Conduct R. 1.1 (2008). Forty-nine jurisdictions, including the District of Columbia and the Virgin Islands, have adopted the Model Rules. See American Bar Association, Center for Professional Responsibility, Model Rules of Professional Conduct, Dates of Adoption, http://www.abanet.org/cpr/mrpc/alpha_states.html (last visited May 9, 2009).

202. Of course, not all clients, even sophisticated ones, want lawyers to draft contracts using clear language. See MACAUlAy, KidWELl \& WhitFord, supra note 20, at 244. Clients want to perceive that they are getting value for their money and, to them, complex language - which is often, but not always, unclear-is a form of power. See id. In some cases, it might also be part of a lawyer's duty to write clearly so a client can understand its obligations. Of course, even where a lawyer's use of ambiguous language is 
In certain cases, a lawyer could cost a client money by drafting an ambiguous contract. For example, a contract written in plain English could save management money by avoiding unnecessary grievances, costly arbitration hearings, and even work stoppages caused by worker discontent over a misinterpreted contract provision. ${ }^{203}$ The lawyer could also hurt the client's legal position by using ambiguous language. For example, the U.S. Court of Appeals for the Sixth Circuit held in a 2007 decision that federal courts may not review an arbitrator's interpretation of language if the language is ambiguous or arguably equivocal. ${ }^{204}$ Because the language of the contract was ambiguous in that case, the arbitrator was able to interpret it however he wanted and against the appellant ${ }^{205}$ The appellant's lawyer could have avoided the adverse result and preserved the client's right to judicial review had the language in the contract been drafted clearly (in support of the appellant's position).

\section{Duty to the Profession}

Model Rule 8.4(c) and its corollary DR 1-102(A)(4) in the Model Code of Professional Responsibility prohibit attorneys from engaging in "conduct involving dishonesty, fraud, deceit or misrepresentation." ${ }^{206}$ While the ABA/BNA Lawyers' Manual on Professional Conduct does not cite any ethics opinion related to those rules on using ambiguous contract language, ${ }^{207}$ conscious ambiguity that is not disclosed explicitly to the other contracting party and waived possibly violates Model Rule 8.4(c). In Informal Opinion 86-1518, the American Bar Association Committee on Ethics and Professional Responsibility found that a lawyer could not have his or her client sign an agreement with a missing agreed-upon term without revealing to the other

in the best interest of his or her client (e.g., perhaps the drafting of URI's attorneys in Cerberus), it often should be discouraged because of the lawyer's competing duties to the legal profession. See infra Part IV.B.2.

203. Suchan \& Scott, supra note 175 , at 25.

204. Mich. Family Res., Inc. v. Serv. Employees Int' 1 Union Local 517 M, 475 F.3d 746, 754-57 (6th Cir.), cert. denied, 127 S. Ct. 1996 (2007).

205. See id.

206. Model Rules of Prof'L Conduct R. 8.4(c) (2008); Model Code of Prof'L Responsibility DR 1-102 (1980)

207. See Am. Bar Ass'n \& Bureau of Nat'l Affairs, ABA/BNA Lawyers' Manual on Professional Conduct $\S 1: 01.401$ (2008). 
party (who would perhaps be disadvantaged by the missing term) that the term was missing. ${ }^{208}$ The Committee said:

Where the lawyer for a has received for signature from the lawyer for $\mathrm{b}$ the final transcription of a contract from which an important provision previously agreed upon has been inadvertently omitted by the lawyer for $b$, the lawyer for a, unintentionally advantaged, should contact the lawyer for $b$ to correct the error and need not consult a about the error. ${ }^{209}$

Further, in Hennig v. Ahearn, the court held that a lawyer possibly had a duty to disclose to the other party where it made a material alteration to the written contract at the last minute, without telling the other party. ${ }^{210}$ It is also possibly a violation of the disciplinary rules in a case in which the contractual term is not missing but it is patently ambiguous, e.g., inconsistent, for the lawyer with knowledge of the ambiguity not to disclose it to the other party.

Although a lawyer should be a zealous advocate, ${ }^{211}$ there should be a limit on that zealousness. ${ }^{212}$ In cases of conscious ambiguity, a lawyer should be under an obligation to disclose the ambiguity to the other party to the contract. The other party might agree to the ambiguous language but, more often than not, the parties might eliminate the ambiguity. While Cerberus is perhaps a borderline case because URI's attorneys had reason to know of the ambiguous language, URI's attorneys still had an obligation to disclose and seek Cerberus's agreement to the inconsistencies in the Merger Agreement.

\section{Doctrines to Discourage Conscious Ambiguity}

This Article does not propose sweeping reform to legal education and legal practice so that lawyers draft clearer contracts, ${ }^{213}$ nor does it

208. ABA Comm. on Ethics and Prof'1 Responsibility, Informal Op. 86-1518 (1986) [hereinafter Op. 86-1518]. For a general discussion of Model Rule 8.4(c), see Peter R. Jarvis \& Bradley F. Tellam, The Dishonesty Rule - A Rule with a Future, 74 OR. L. Rev. 665 (1995).

209. Op. 86-1518, supra note 208.

210. 601 N.W.2d 14, 22-23 (Wis. Ct. App. 1999).

211. See supra note 189.

212. The preamble of the Model Rules of Professional Conduct even acknowledges that the lawyer has other roles that he or she must balance in addition to the role of zealous advocate, including the roles of advisor, negotiator, and evaluator. See Model Rules of Prof’L Conduct pmbl. \ 2 (2008).

213. To the extent that the reason for ambiguous language is sloppiness, there are many possible ways to address this problem, including more skills-based training in law school and more mentoring of law firm associates. Another possibility is that lawyers might be less likely to cut corners in drafting and editing documents if they billed on a per-deal rather than a per-hour basis so that their clients put less pressure on them to reduce their hours billed. 
comprehensively detail how the rules of professional responsibility can be used to deter conscious ambiguity. However, it begins to address the role of contract doctrine and theory in preventing these problems. Part III of this Article discussed three doctrines that courts have used in interpreting ambiguous contracts with inconsistencies. This part revisits those doctrines in the context of courts disincentivizing conscious ambiguity, suggesting that courts apply the forthright negotiator principle and contra proferentem, and reject the four corners rule.

\section{A. The Forthright Negotiator Principle}

The attention that Vice Chancellor Chandler's opinion gave to the forthright negotiator principle is a welcome development in contracts law. Vice Chancellor Chandler could have merely cited the relevant restatement section. ${ }^{214}$ However, by invoking the concept of a "forthright negotiator," the opinion leaves the impression that URI's lawyers were not forthright in insisting upon and agreeing to an injunctive right in the Merger Agreement, knowing full well that Cerberus's lawyers thought the injunctive right was irrelevant in light of the limitation of URI's remedies to the reversetermination fee. This impression is at least consistent with the ethical obligations of URI's attorneys, ${ }^{215}$ and, apart from the substance of the forthright negotiator doctrine, suggests to deal lawyers that they should avoid, or at least disclose, ambiguity in the first instance. ${ }^{216}$ That should decrease the need to apply the forthright negotiator principle.

As a doctrinal matter, the objective theory of contract has never shunned subjective intentions entirely. ${ }^{217}$ For example, a party to a contract can introduce subjective evidence to show that there was a mutual mistake at the time of contracting. ${ }^{218}$ In Cerberus, the written contract was unhelpful in

214. See Restatement (Second) of Contracts $§ 201(2)$ (1981).

215. See supra Part IV.B.2.

216. As a matter of doctrine, the obscurity of the principle should not undermine its significance. It is true that most contracts in general, and M\&A deals in particular, never reach a courtroom because "the agreements fall within the self-enforcing range or can be enforced with reputational sanctions." Schwartz \& Scott, supra note 30, at 557. However, the widespread publication of the principle itself gives lawyers an incentive to avoid "conscious ambiguity" in the first place.

217. See Barnett, supra note 38, at 308 ("But unlike a will theory, a consent theory, because it is based on fundamental notions of entitlements, can explain both why we generally enforce the objective manifestation of consent when it differs from subjective intent and the exceptions where evidence of subjective intent will prevail.").

218. See, e.g., FARNSWORTH, supra note $39, \S 9.3$, at 605 ("A mutual mistake occurs when both parties are under substantially the same erroneous perception as to the facts."). 
interpreting whether the parties intended for URI to have an injunctive right upon Cerberus's breach, so a repudiation of subjective evidence would have required Vice Chancellor Chandler to guess at what the parties had intended. Because we do not want to hold parties to promises to which they did not manifest assent ${ }^{219}$ the forthright negotiator principle is helpful. When a party, such as URI in Cerberus, knows or has reason to know of the other party's subjective intentions, it agrees to be bound by them if the language as to those intentions in the parties' agreement is ambiguous.

\section{B. Contra Proferentem}

The focus of this Article so far has largely been on M\&A deals and other contracts where both parties are sophisticated and are represented by counsel, and where the parties have relatively equal bargaining power. In this context, such as in Cerberus, it is difficult to think of only one party as the drafter (and therefore more responsible for the language in the contract) because often attorneys copy stock clauses ${ }^{220}$ and exchange drafts of the contract several times. ${ }^{221}$ Many of these contracts even have a clause precluding the application of contra proferentem, i.e., a clause that the contract should not be construed against the party who drafted the contract. ${ }^{222}$

However, in a form contract, such as an insurance or other type of consumer contract, one party often has no leverage over the terms of the agreement. ${ }^{223}$ Where only one party has the responsibility for drafting language, application of contra proferentem, either as a tie-breaker or as a

219. See Barnett, supra note 38, at 319 (“A consent theory of contractual obligation views certain agreements as legally binding because the parties bring to the transaction certain rights and they manifest their assent to the transfer of these rights.").

220. See Macaulay, Kidwell \& Whitford, supra note 20, at 244.

221. See, e.g., Keven J. Davis \& Pamela R. Lester, Exclusivity in Contract: The Athlete's View, SM009 ALI-ABA 285 (Jan. 25-27, 2007). The drafting in Cerberus is also an example of where the parties exchanged numerous drafts. See United Rentals, Inc. v. RAM Holdings, Inc., 937 A.2d 810, 820-27 (Del. Ch. 2007).

222. See Davis Medical Electronics, Inc., http://www.davismedical.com/resources/DocRequest/S-AContract.pdf (last visited May 9, 2009) ("Ambiguities or inconsistencies in this Agreement (including its Exhibits or Schedules if any) shall not be construed against the drafter as drafter.").

223. See, e.g., Richard M. Alderman, Consumer Arbitration: The Destruction of the Common Law, 2 J. AM. ARB. 1, $9 \&$ n. 41 (2003) (noting that consumer contracts that contain mandatory arbitration clauses often afford individuals no leverage and they have no alternative but to sign the agreements). 
primary rule of construction, ${ }^{224}$ gives that party at least some disincentive to introduce ambiguity into the contract. ${ }^{225}$

This does not mean that contra proferentem, especially as applied, is without its critics. Michelle Boardman argues that when contra proferentem is used in insurance contracts, it creates a feedback loop where insurance companies have no incentive to clarify in what historically has been unclear boilerplate in insurance contracts. ${ }^{226}$ Boardman argues that courts use contra proferentem to interpret even those contracts that are not ambiguous, giving the insurance companies certainty in how courts interpret terms, which allows them to account for the outcome (in addition to the risk) of litigation in their pricing of insurance. ${ }^{227}$ Of course, her criticism is with contra proferentem as applied and not with the doctrine itself, and courts should not find ambiguity in contracts unless it exists. To the extent that consumer contracts remain unreadable, the solution might be in other judicial ${ }^{228}$ and legislative checks. ${ }^{229}$

\section{Four Corners Rule}

This Article rejects the position of Professors Schwartz and Scott. They advocate applying the four corners rule, or Willistonian rule, of contract interpretation as the majoritarian default rule that most parties would prefer courts to apply. ${ }^{230}$ To think of the four corners rule as a default rule is problematic in and of itself, as it is an evidentiary rule that courts do not give parties the discretion to choose. However, it is also unclear whether most parties would prefer this default. Some parties might choose it-e.g., URI in Cerberus, as it would have given the equipment lessor the best chance of

224. See supra note 147.

225. See supra note 137.

226. See Boardman, supra note 136, at 1121-26.

227. See id. Others have argued for specific modifications to the doctrine of contra proferentem, all of which merit discussion and are not foreclosed by the arguments in this Article. One commentator, for example, suggested that "the ambiguity rule might be applied only when an ambiguity is unreasonable or negligent." See Michael B. Rappaport, The Ambiguity Rule and Insurance Law: Why Insurance Contracts Should Not Be Construed Against the Drafter, 30 GA. L. Rev. 171, 256 (1995). Put another way, contra proferentem might be applied only where ambiguity is negligent or conscious.

228. See Braucher, supra note 38 , at 712 .

229. In many jurisdictions, there is also a statutory obligation to write clear consumer contracts. See, e.g., Conn. Gen. Stat. Ann. § 42-152 (West 2007); Mont. Code Ann. § 30-13-1103 (2007); N.J. Stat. ANN. § 56:12-2 (West 2001); Or. Rev. STAt. § 180-545 (2007). Within an organization, clear contracts (e.g., labor contracts) can also create trust between parties (e.g., management and labor). See Suchan \& Scott, supra note 175 , at 22-23.

230. Schwartz \& Scott, supra note 30, at 569. 
winning - but other parties would not - e.g., Cerberus, whose case was stronger because the court fully evaluated the extrinsic evidence. Moreover, there is an irony in introducing interpretative questions over rules of interpretation "in creating an incentive for parties to write contracts in majority talk [or language understood by the court]."231

Schwartz and Scott's idea that the four corners rule would make courts most likely to interpret contracts consistent with what the parties intended does not necessarily follow. For example, even if URI and Cerberus were to choose in the Merger Agreement the four corners rule as the court's interpretative style upon default, URI would not have had any incentive to abandon the injunctive right and eliminate the apparent inconsistencies that ultimately confronted the court. In a choice between a superseded injunctive right and no injunctive right at all, the first gave Cerberus a better chance in litigation than the second. While I agree with Schwartz and Scott that contracts that are understandable by the courts is the goal, abandoning extrinsic evidence in the court's consideration of whether a contract is ambiguous will not, in some cases, produce clearer contracts. Without courts considering extrinsic evidence, the incentive for conscious ambiguity still exists. $^{232}$

In Cerberus, Vice Chancellor Chandler applied the four corners rule, but made the correct decision. ${ }^{233}$ Cerberus illustrates two problems with the rule. Even when the court purports to be applying the four corners rule, there is nothing to preclude the court from considering extrinsic evidence. ${ }^{234}$ The rule's impact is therefore likely overstated. Second, as in Cerberus where the court was potentially "exceedingly close" to getting the "incorrect answer" without hearing the extrinsic evidence, ${ }^{235}$ the four corners rule almost prevented the court from getting the answer right.

231. Id. at 572 .

232. One problem with application of the four corners rule to form contracts is that it does not allow for consideration of concerns of fairness that are not present on the "four corners" of a contract. See Larry A. DiMatteo, The Norms of Contract: The Fairness Inquiry and the "Law of Satisfaction"-A Nonunified Theory, 24 Hofstra L. Rev. 349, 432 (1995).

233. See supra note 113.

234. See id.

235. See id. 


\section{COnClusion: Empirical Questions}

The negotiations preceding the URI-Cerberus merger, the ensuing lawsuit, and Vice Chancellor Chandler's opinion offer valuable lessons for deal lawyers. However, at the core, Cerberus was nothing more than a "good, old-fashioned contract case of buyer's remorse."236 Though old-fashioned, Cerberus offers an excellent case study of conscious ambiguity-lawyers agreeing to contract language that they most likely knew had the appearance of inconsistency. If URI had prevailed, the overriding message to take away from the case might have been how URI's lawyers leveraged language to negotiate a deal and to exercise their litigation option when the deal went awry, and how Cerberus's attorneys stood idle while the parties signed a Merger Agreement that potentially preserved an injunctive option for URI to which Cerberus did not agree. Instead, because Cerberus was successful, the message to deal lawyers is to draft contracts clearly and not to use consciously ambiguous language as a negotiation tactic in trying to reach a deal.

While Cerberus raises significant doctrinal, theoretical, and ethical issues, it leaves deal lawyers and contract scholars with lingering questions regarding the reality of how lawyers draft contracts. ${ }^{237}$ In broad terms, the question remains of the extent to which Professor Coates in his expert report in Cerberus accurately captured M\&A drafting practices.

More specifically, do lawyers intentionally draft contracts with ambiguous language to facilitate getting "the deal done"? Do lawyers find such a practice acceptable? The answer is likely not so black and white. Is there a point where language is so unclear (e.g., it is sufficiently ambiguous even in context because it is inconsistent) that lawyers would not leave it in a contract even if it benefited their client? Do lawyers perceive that they have an obligation to identify language that is inconsistent with the parties' agreement and disclose its existence to lawyers representing other parties to the deal? Do the answers to these questions differ between men and women, across races, or among lawyers practicing in various geographical locations?

The other group of questions revolves around the extent to which lawyers perceive that unclear language (either as a result of sloppiness or "planned obfuscation") is necessary "to get deals done." Are the cost and time pressures on lawyers so great that they cannot review each provision of a merger

236. United Rentals, Inc. v. RAM Holdings, Inc., 937 A.2d 810, 844-45 (Del. Ch. 2007).

237. I am beginning a study where I interview M\&A practitioners to begin to get answers to some of these questions. 
agreement closely? Are uses of "subject to" and "notwithstanding" and other linguistic shortcuts the most effective way to articulate their agreements and, if not, do lawyers feel that the legal and business culture requires them to use those terms? Most significantly, do lawyers perceive that they need to use language that is ambiguous at the risk of not otherwise consummating a deal?

Cerberus as protector of the underworld is only a myth. But the vivid image of the mythological beast should paint a colorful reminder of the pitfalls for lawyers of intentionally drafting unclear language the next time that they negotiate a contract. Courts can do their part in using doctrine, such as the forthright negotiator principle and contra proferentem, that discourages conscious ambiguity in drafting. In the case of consumer contracts, further judicial and legislative intervention might be necessary to reverse a longstanding practice of unclear boilerplate. ${ }^{238}$ As for contracts scholars, this Article should be only the beginning of the study of drafting practices in M\&A deals. 